\title{
Reflexões acerca da Técnica Composicional
}

\author{
Reflections on the Compositional Technique
}

\section{Flávio Santos Pereira \\ Universidade de Brasília \\ flaviosp@unb.br}

Resumo: este artigo traz um conjunto de reflexões acerca da técnica composicional, da perspectiva da construção da técnica de composição musical do próprio autor, considerando-a em relação ao próprio compositor que a pratica, ao 'pensamento complexo' de Morin, à oposição natureza e cultura, ao léxico, signo e significado musical, aos princípios composicionais da complementaridade e eixos cromáticos, à elaboração motívico-temática.

Palavras-chave: técnica composicional; preordenação; semantização.

Abstract: this article presents a set of reflections about compositional technique, from the perspective of the construction of the technique of musical composition of the author himself. It considers the compositional technique in relation to the composer himself who practices it, the 'complex thinking' of Morin, the opposition between nature and culture, the lexicon, sign and musical meaning, the compositional principles of complementarity and chromatic axes, the motive-thematic elaboration.

Keywords: compositional technique; preordering; semantization.

\section{1 - Introdução}

[...] imagina apenas uma ordem humana total, universal, em suma uma ordem civil perfeita: eu afirmo, essa é a morte pelo frio, a rigidez cadavérica, uma paisagem lunar, uma epidemia geométrica!

[...] De alguma forma a ordem passa a ser desejo de matar. (Musil, Robert. O homem sem qualidades. Rio de Janeiro: Nova Fronteira 2006, p. 497) 
Este artigo traz um conjunto de reflexões feitas a partir da prática composicional do próprio autor, prática esta que se apoiou, num primeiro momento, em técnicas baseadas em princípios de preordenação. Entretanto, ao longo do tempo, foram abandonados estes princípios de preordenação em favor de princípios de 'semantização', onde as figuras que atuam na construção do discurso musical obedecem a princípios composicionais orientadores, porém, não deterministas.

Nattiez (2005, p.171) no texto em que discursa sobre a fidelidade e a autenticidade, a se referir à posição de Peter Kivy (1995), escreve que este se opõe "ao culto do compositor-que-tudo-sabe-de-sua-obra". Em verdade, são demasiadas as decisões arbitrárias e os axiomas adotados pelo compositor no processo composicional: se este convive estreita e plenamente com cada detalhe da obra no seu processo de concepção, de nenhum modo é capaz de estabelecer todas as suas causas como consequências da dinâmica de um sistema lógico e coerente, se tomamos estes conceitos como índices da racionalidade inerente aos processos composicionais. Identificar as forças dominantes torna-se ainda mais complexo em períodos em que o compositor se impõe uma reavaliação da sua estética e, consequentemente, dos seus recursos técnicos.

Este conjunto de reflexões representa o esforço de conscientização e de formação de uma visão sistemática dos processos postos em ação pelo próprio compositor na sua atividade criadora. No nosso caso, em particular, a questão da significação, a experiência sensível com a obra musical, o desejo de deslocar ideias e emoções no ouvinte, fazê-lo tomar parte de um percurso intelectoemocional, tornaram-se, gradualmente, norteadores do processo composicional.

A relação da técnica composicional com a teoria musical é direta e recíproca. A teoria nutre-se da produção composicional num esforço constante para extrair conceitos gerais das inúmeras práticas individuais. Estas, as práticas individuais, constroem-se sobre este conhecimento, de domínio do coletivo, a teoria musical, para formar o seu discurso. Neste sentido, as reflexões sobre a técnica da composição musical inserem-se no grande campo da teoria musical, dando-lhe elementos para a permanente expansão.

\section{2 - A dupla condição do compositor de observador e observado}

Ao compositor é imposta a reflexão acerca da técnica composicional. Mesmo que esta não se formalize, impõe-se no exercício cotidiano da atividade criativa, materializando-se na própria obra. A reflexão acerca da técnica composicional só é válida e frutífera se a pensarmos como componente intrínseco e inseparável do estilo. Como o afirma Stravinsky (1984, p. 19), a técnica é “o homem por inteiro". Complementa: 
Uma técnica ou um estilo para se dizer algo de original não existe a priori, eles são criados pela própria forma original de dizer. [...] A 'ideia' não é uma coisa e a 'técnica' outra, isto é a habilidade de transferir, de 'expressar' ou desenvolver pensamentos. [... A técnica é] criação, e, como tal, é constantemente nova. (Stravinsky 1984, p. 19)

A técnica está de tal modo entranhada no estilo e expressão que só artificiosamente podemos destacá-la e evidenciar suas funções. O seu reflexo no estilo é imediato, pois é este quem a determina numa relação dialética.

O esforço para constituir a técnica composicional, de modo que torne possível a materialização dos anseios expressivos - desde o início determinantes no processo mesmo da constituição -, em que o compositor vislumbre um território afim com suas preocupações de ordem estética e emocional, exige uma permanente reflexão. $\mathrm{O}$ abandono por este autor dos procedimentos composicionais cuja origem e princípio é a preordenação - do que a música serial, embora exemplar, é apenas um dos muitos casos - resultou de uma insatisfação fundamental no plano expressivo. A recusa da técnica composicional decorrente deste princípio, a preordenação, é, entretanto, uma manifestação superficial, porém inevitável, de um fenômeno muito mais profundo, que é a constituição de uma linguagem intrinsecamente capaz de servir ao compositor como um instrumento de representação. Uma linguagem que já traga consigo, no seu próprio processo de formulação, as medidas da armadura do conteúdo que the dará vida.

A definição, escolha e adesão a um conjunto de técnicas composicionais jamais devem se apoiar nos frágeis alicerces da recusa e da negação. Os instrumentos de que se serve o processo criativo devem encontrar a sua justificação, positiva, no projeto estético do compositor. Neste sentido, a determinação de não mais empregar uma técnica composicional fundada na preordenação é, acima de tudo, consequência da insatisfação com os projetos estéticos que a orientam e, pode-se afirmar, legitimam. Trata-se, enfim, de fazer uma escolha cuja repercussão maior está no âmbito da satisfação pessoal, uma satisfação que tem exigências nos planos estético, técnico e expressivo. Satisfação que, embora originariamente pessoal, do âmbito do indivíduo, pode encarnar uma ansiedade coletiva, de ordem social.

Serão expostas neste artigo aquelas posturas e procedimentos técnicos que parecem essenciais ao autor na definição do próprio estilo. Tem-se a plena consciência dos riscos de uma abordagem desta natureza. Sabe-se da dificuldade para se alcançar o distanciamento necessário para assumir os julgamentos de valor que são intrínsecos, quando se decide por uma hierarquia e importância das ferramentas que de fato determinam o estilo. As advertências são inumeráveis, e podem ser resumidas na admoestação de Boulez (1972, p. 15-17): 
Continuo persuadido de que o autor, por mais perspicaz que seja, não pode conceber as consequências - próximas ou longínquas - do que ele escreveu, e que sua ótica não é forçosamente mais aguda que a do analista (tal como o entendo). Certos procedimentos, resultados, maneiras de inventar, que lhe tinham parecido primordiais quando os descobriu, envelhecerão ou continuarão a ser puramente pessoais; e ele terá considerado como dispensáveis ou como detalhes secundários visões de conjunto que se revelarão, tardiamente, de importância capital. É um grave dano confundir o valor da obra, ou sua novidade imediata, com seu eventual poder de fertilizar.

[...] Certamente, quando se vive, dia a dia, sua experiência criadora, é difícil, para não dizer impossível por vezes, afastar suas preocupações diretas, imediatas, para fazer, com o distanciamento necessário, uma crítica clarividente, com lucidez e intransigência, dos resultados em curso.

Há ainda o desconforto, manifesto em inúmeros depoimentos, em tratar da própria linguagem. Como o expõe Murail (2005, p. 149):

Às vezes, é sem dúvida necessário para o compositor refletir sobre o seu método. Mas deve ele expressar estas reflexões? Falar sobre si mesmo traz riscos: limitase o próprio desenvolvimento, a autocensura. A este respeito, cabe realmente ao compositor construir suas próprias teorias? Isto não pressupõe uma falha de nossa musicologia? Se o ato da observação perturba o objeto observado, o que podemos dizer quando o observado e o observador fundem-se em um só?

Este desconforto não é causado só pelo incômodo de expor a 'intimidade' da obra, pelo temor de ver esvair o seu mistério, que, a bem da verdade, se situa em outro plano ainda inescrutável, o plano das motivações determinadoras das escolhas e decisões. Este desconforto tem a sua origem na consciência de que, quando se trata de aspectos técnicos, sobretudo quando nos detemos exclusivamente neles, isolando-os das forças que os justificam, estes assumem uma importância e dominância que é uma usurpação da posição que de fato cabe à expressão - que obrigatoriamente os inclui -, a qual temos nos mostrado pouco preparados quando não temerosos em abordar. Há, enfim, justificável, o temor de que aspectos parciais e interesses técnicos específicos possam turbar ou desviar a atenção da impressão geral que se pretende alcançar na experiência sensório-intelectual com a totalidade da obra. As análises predominantemente técnicas têm muito do espírito da dissecação, do interesse anatômico próprio das autópsias. Longe de esclarecer o sentido, situam-se à sua margem, nada informando do espírito que mantém a obra viva.

Quanto ao distanciamento, a que se refere tanto Boulez quanto Murail, está demonstrado nas ciências sociais, de onde podemos tomar o exemplo, que é muito mais fomentador e estimulante a multiplicidade de perspectivas, das mais variadas distâncias, inclusive da proximidade entre observador e observado, quando obnubilado o limiar que separa um do outro. Como na antropologia, 
haveria de chegar o momento em que o 'nativo' faria ouvir a sua voz, a exemplo do sociólogo, condição especial de 'nativo', cujo campo de estudo é a própria sociedade na qual está imerso, ou, ao menos, um grupo dentro daquela de cuja influência não está isento. Ademais, o 'nativo' tem o direito da pretensão à objetividade, como é o caso, por exemplo, com Stravinsky (1977, p. 13):

[...] não será um conjunto de opiniões que lhes proponho, senão uma soma de comprovações que lhes submeto, e que, feitas por mim, não são menos válidas para os demais.

Não se trata, pois, de meus sentimentos e de meus gostos particulares. Não se trata de uma teoria da música projetada através do prisma subjetivista. Minhas experiências e investigações são inteiramente objetivas e minhas introspecções não me têm levado a me interrogar senão para extrair consequências concretas.

Neste caso, falar da própria obra, seu aparato técnico, os propósitos estéticos que norteiam ou são resultado de suas decisões, apesar da parcialidade, dos equívocos que possa conter, vemos ainda sobressair o interesse pela visão particular do compositor, que jamais será prejudicial se não se lhe conceder $a$ priori qualquer privilégio defronte às demais interpretações críticas que cercam a sua obra, se não se lhe conceder uma posição especial, seguramente perturbadora de uma visão de conjunto.

Abordaremos as questões técnicas com a visão crítica do que estas podem dar para o entendimento da obra, cientes de que podem dar muito pouco. Assinalemos, uma obra não se afirma somente pelo bem justificado emprego das técnicas composicionais. Este não é mais do que um requisito mínimo. Vejamos o exemplo que nos dá o estudo da gramática na linguagem articulada, em que o estudo da técnica é feito artificiosamente à margem do sentido, a identificar a natureza e estabelecer as posições formais dos termos sintáticos. Encontramos alguns sinais do estilo, mas dali vislumbramos pouco mais do que o horizonte do sentido. Temos, entretanto, a consciência de que da abordagem da técnica composicional podemos obter indícios razoavelmente seguros dos suportes onde se assentam o conteúdo, podemos fazer desta, a abordagem técnica, um dos termos de orientação para nos dirigirmos, menos inseguros, para a muito mais interessante região da experiência estética, região de indevassáveis mistérios e, por isso mesmo, de permanente fascínio, região onde se situa a significação.

A primeira experiência com uma prática inserida em uma concepção estética onde é do compositor a responsabilidade plena por todas as decisões, em todos os níveis - sem o recurso a qualquer 'muleta' - foi a composição por este autor de Obra Eletrônica I. ${ }^{1}$ Cabe aqui uma consideração motivada pela análise de Rose (1996, p. 16) acerca da música espectral:

\footnotetext{
${ }^{1}$ Disponível em https://www.youtube.com/watch?v=KcoysLr5BiY
} 
Os compositores da música espectral têm sido influenciados por diversos processos eletrônicos, além da síntese aditiva: filtragem, modulação por anel, modulação por frequência entre outros. O comportamento conceitual de cada processo é metaforicamente transposto do domínio eletrônico para o acústico.

Como ficará evidente, em oposição ao comportamento conceitual descrito por Rose, adotamos a posição de trabalhar cada material explorando as suas especificidades. Em nenhum momento se busca com determinados meios alcançar resultados que podem ser obtidos de modo muito mais efetivo com outros meios igualmente acessíveis. Nas decisões quanto a que princípios e práticas eleger, de acordo com o propósito estético escolhido, debruça-se sobre as particularidades do material adotado, selecionando para as funções de organização aqueles que se avalia mais capazes e efetivos em razão dos resultados que se pretende alcançar. Este material adotado, na maioria dos casos, traz consigo uma carga histórica, que, longe de ser recusada ou ignorada, é tomada como um dos termos característicos do material, e com esta estabelecemse relações que se multiplicam no interior da obra e, ao mesmo tempo, explicitam o seu conjunto de referências. Esse é o caso, que trataremos mais adiante, por exemplo, dos eixos cromáticos.

\section{3 - A afinidade com o pensamento complexo de Morin}

A nossa prática composicional tem grande afinidade e compartilha muito da ideologia do pensamento complexo. Não se trata de uma adesão ou filiação, porque nossas práticas composicionais não são o resultado de reflexões desencadeadas pelo conhecimento e estudo do 'pensamento complexo', mas motivadas por reflexões desencadeadas no âmbito mesmo da criação musical. A afinidade estabeleceu-se - quando já desenvolvidas as reflexões e práticas que nos levaram à recusa das técnicas fundadas na preordenação - a partir da percepção que os princípios definidores e fundamentais do 'pensamento complexo' descrevem e, ao mesmo tempo, esclarecem muito da nossa postura frente ao ato composicional. Assinalemos que não nos sentimos completamente à vontade, entretanto, em razão mesmo da natureza do processo criativo que empreendemos, com a questão da oposição entre unidade e diferença ou multiplicidade. Escreve Morin (2007, p. 18):

Situo-me, portanto, totalmente fora dos dois clãs antagônicos, um que esmaga a diferença reenviando-a à unidade simples, o outro que oculta a unidade porque só vê a diferença: totalmente fora deles, mas tentando integrar a verdade de um e do outro, isto é, superar a alternativa. 
A ideia de uma unidade da ciência, colocada por Morin (2007, p. 50), como possibilidade e necessidade, "concebível no campo de uma physis generalizada", "capaz de apreender ao mesmo tempo unidade e diversidade, continuidade e rupturas", "possível para uma teoria da auto-eco-organização, aberta sobre uma teoria geral da physis", parece-nos reconstruir em um outro nível a mesma artificialidade que está no cerne da fragmentação do conhecimento e a consequente especialização, condenada por Morin. Na nossa prática composicional, a obra, queremos acreditar, nasce de elementos e termos aptos e já determinados à integração, e cujo sentido primeiro - o sentido propriamente musical outorgado pela sintaxe - está na integração mesma. Um conjunto integrado não é necessariamente um conjunto uno, embora possa provocar essa ilusão. O próprio Morin recorre à ideia de integração ao se referir às transformações por que deve passar a ciência no processo de "integração das realidades banidas pela ciência clássica", o que também tem validade para a arte. Trata-se de "integrar o acaso", "conceber em seu caráter radical e polidimensional a informação", "integrar o meio ambiente", "integrar o ser autoeco-organizado", e "reconhecer o que é sempre silenciado nas teorias da evolução: a inventividade e a criatividade" (Morin 2007, p. 52). Procuraremos esclarecer a nossa posição nas reflexões subsequentes, mas, adiantamos, em relação ao pensamento de Morin, não nos parece essencial "superar a alternativa", embora esta também seja uma possibilidade.

$\mathrm{O}$ 'pensamento complexo' concebe a conjunção do uno e do múltiplo (unitat multiplex). Ao interrogar-se acerca do que é a complexidade, define Morin (2007, p. 13):

A um primeiro olhar, a complexidade é um tecido (complexus: o que é tecido junto) de constituintes heterogêneas inseparavelmente associadas: ela coloca o paradoxo do uno e do múltiplo. Num segundo momento, a complexidade é efetivamente o tecido de acontecimentos, ações, interações, retroações, determinações, acasos, que constituem nosso mundo fenomênico.

Guardemos para a nossa reflexão a ideia de 'constituintes heterogêneas inseparavelmente associadas'; a oposição clássica entre o uno e o múltiplo, elevada à condição de paradoxo pelo pensamento complexo; e o conceito de 'mundo fenomênico', que faz referência direta a nossas faculdades perceptivas.

$\mathrm{O}$ cruzamento de diversas ações composicionais aplicadas à matéria sonora, vinculadas a um princípio unificador, para se alcançar resultados perceptivelmente semelhantes, expressivos da identidade, tem vínculo com o princípio clássico da unidade, onde o múltiplo como princípio originário é associado à imperfeição. Não só em música, a polaridade entre o uno e o múltiplo, a redução de situações complexas a fórmulas simples, sempre exerceu e continua a exercer enorme atração. Stravinsky (1977, p. 36) - ao abordar os 
princípios de similaridade e contraste, 'que dominam o processo criador', e aos quais faz corresponder as noções essenciais de unidade e variedade - mostra o seu fascínio:

[...] tenho considerado sempre que, em geral, é mais satisfatório proceder por similaridade do que por contraste. [...] O Contraste produz um efeito imediato. A similaridade nos satisfaz a longo prazo. O contraste é elemento de variedade, mas divide nossa atenção. A similaridade nasce de um esforço pela unidade. A necessidade de se buscar a variedade é perfeitamente legítima, mas não devemos esquecer que o Uno precede o Múltiplo.

Stravinsky expressa o pensamento dominante pela precedência e posição hierárquica superior do Uno. Adotamos outro posicionamento. A partir de uma perspectiva fenomênica, cada dimensão ou 'constituinte heterogênea', embora a compartilhar normas e características, manifestará propriedades que lhe são próprias e distintivas. Assim, mesmo com áreas em comum, não são os mesmos os princípios que adotaremos para governar, por exemplo, os planos horizontal e vertical, ou melódico e harmônico. Não nos sentimos compelidos a alcançar uma forma inexoravelmente deduzida do material, antes a explorar modelos de conciliação entre as várias instâncias que serão postas em relação, mas que têm características irredutivelmente distintas, ou até, quando for o caso, a explorar modelos de contradição, sem aplacar os atritos perceptíveis, como ocorre, por exemplo, na última reapresentação do material temático inicial de Solo para Violoncelo, nos compassos 117 a 122, (vide Exemplo 1) em que a história construída sobre este material está em franca oposição ao perfil dinâmico que lhe é associado neste momento, mas que tem por propósito desencadear a tensão, pelo inesperado do perfil dinâmico, que leva ao final enérgico do primeiro movimento, mas que também provoca e, ao mesmo tempo, resolve-se no segundo movimento, que o sucede. É a solução que aplicamos, neste caso específico, para legitimar a composição em vários movimentos: criar contextos em um movimento que desencadeiam relações e reações que avançam sobre os demais movimentos da obra. 

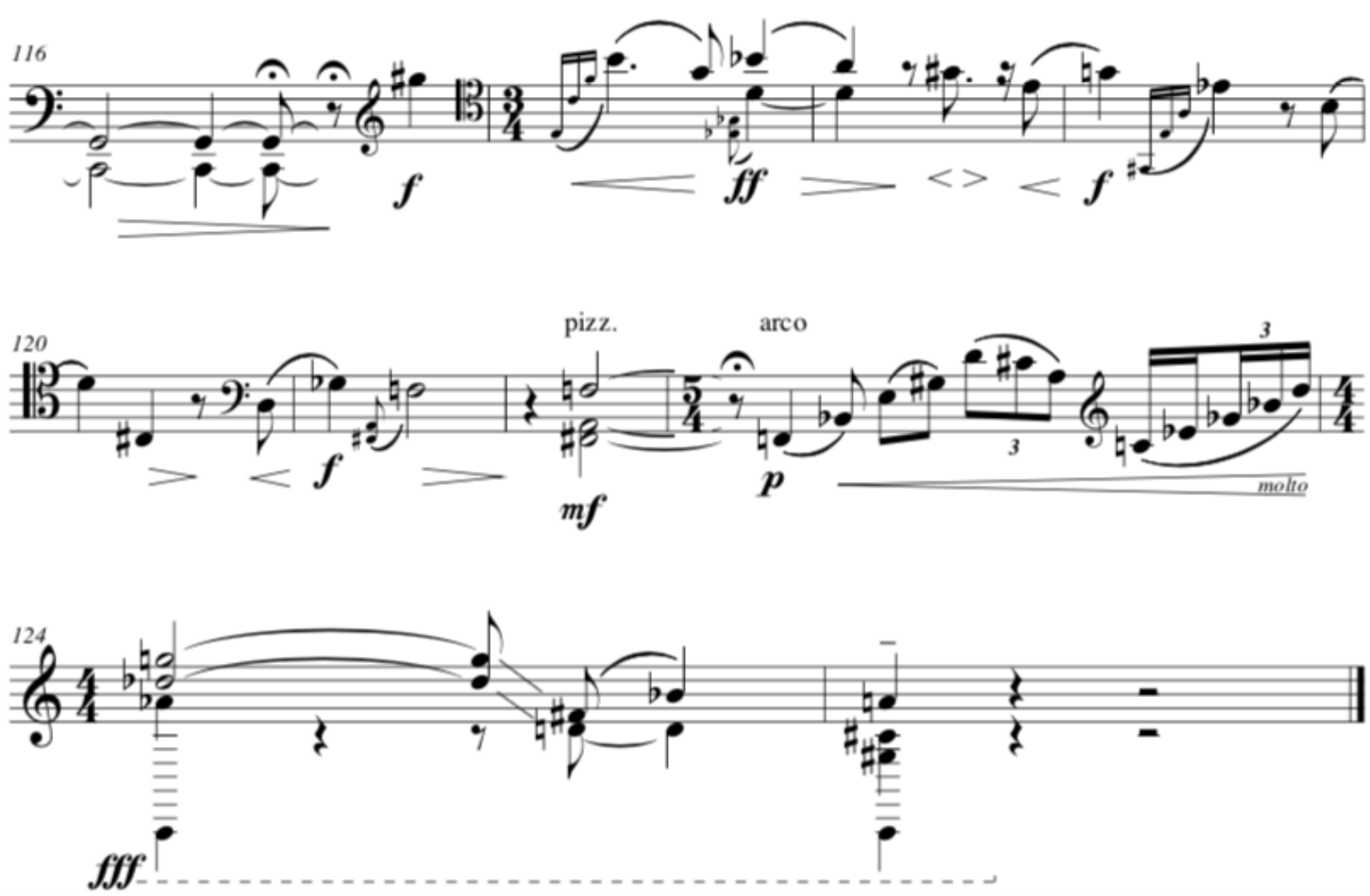

Exemplo 1: Solo para Violoncelo: reapresentação do material temático inicial, compassos 117 a 122

Não há razão, em nosso entendimento, para se buscar ou que determine um princípio gerador comum, nos moldes do pensamento clássico, quando este princípio é simplificador e redutor do fenômeno - desencadeador de uma metalinguagem do fenômeno, muitas vezes expressa em fórmulas, que, ao mesmo tempo, remete e distancia -, e quando a diversidade de concepções possibilita, dentro dos propósitos do autor, uma abordagem onde é possível um maior aprofundamento nas idiossincrasias de cada aspecto a interagir na composição da textura. O princípio clássico da unidade, ele mesmo, é essencialmente redutor ao privilegiar, arbitrariamente, aqueles fenômenos que forjam a identidade, e, ao mesmo tempo, desconsiderar ou subestimar a importância daqueles fenômenos que expõem e permitem explorar a multiplicidade do real. Reconhecemos e aceitamos a validade do fixar-se no monismo de um único princípio ordenador, mas consideramos igualmente válido partir da pluralidade de princípios organizadores, sem que estes, necessariamente, sejam originários de um princípio unificador ou que venham desembocar neste. Não é neste estágio que, acreditamos, se deva questionar a legitimidade ou o valor estético da obra. Trata-se mais de uma idiossincrasia do compositor no seu processo criativo. O importante, parece-nos, é não se deixar dominar pela quase obsessão do tema da unidade como condição a ser satisfeita para que a obra se eleve ao reconhecido estado de 'obra de arte' como expressão de um estado de perfeição. Parece-nos, aliás, que esta é uma condição em total 
PEREIRA, Flávio. 2018. Reflexões acerca da Técnica Composicional. MUSICA THEORICA. Salvador: TeMA, 201606, p.128-174.

contradição com o pensamento e práticas atuais, marcados por uma diversidade estética e técnica sem precedentes.

O princípio da unidade é, e sempre tem sido, uma das faces do pensamento simplificador, por meio do qual se tem buscado 'ordem e clareza no real', desvelar 'as leis que o governam'. "Mas", adverte Morin (2007, p. 5), “se resulta que os modos simplificadores de conhecimento mutilam mais do que exprimem as realidades ou os fenômenos de que tratam, torna-se evidente que eles produzem mais cegueira do que elucidação".

O pensamento que gere o processo criativo como o idealizamos reconhecese nas características descritas por Morin (2007, p. 6-7) na definição do pensamento complexo:

[...] o pensamento complexo integra o mais possível os modos simplificadores de pensar, mas recusa as consequências mutiladoras, redutoras, unidimensionais e finalmente ofuscantes de uma simplificação que se considera reflexo do que há de real na realidade. [... traz] em seu princípio o reconhecimento dos laços entre as entidades que nosso pensamento deve necessariamente distinguir, mas não isolar umas das outras. [...] é animado por uma tensão permanente entre a aspiração a um saber não fragmentado, não compartimentado, não redutor, e o reconhecimento do inacabado e da incompletude de qualquer conhecimento.

A obra musical, como a procuramos constituir, em sintonia com a estética que cultivamos, não é suscetível de uma análise que a exaure, não se permite a redução a um conjunto de princípios que a explique e determine como resultado da aplicação destes mesmos princípios gerais, passíveis de abstração e afastamento do fenômeno que se pretende explicar. Mas admite a formulação de princípios que a tome como uma possibilidade, determinada não pelos princípios mesmos, mas por uma complexa sucessão de escolhas que os aplica. Ao contrário da tonalidade, que tem na escala o princípio de toda a organização no plano das alturas; da música serial, que tem na série o princípio da organização dos diversos parâmetros; no nosso caso, para ficarmos na problemática da organização das alturas, ao invés de um 'objeto concreto' - seja um modo, escala, conjunto específico de alturas (pitch class), série, sonoridades colhidas in natura-

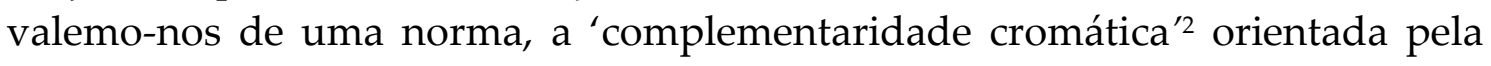
'elaboração motívico-temática'. A norma não é determinista, antes um ponto cardeal. Orienta a escolha dos termos sobre os quais operará a organização

\footnotetext{
${ }^{2}$ A complementaridade cromática é a tendência, mas somente a tendência, da manifestação do total cromático, quaisquer que sejam os termos escolhidos para definir este total cromático, que, no nosso caso, é composto dos 12 sons da escala temperada. A complementaridade cromática tende a impedir a hierarquização dos termos, a qual, entretanto, pode ocorrer ocasional e mesmo voluntariamente.
} 
musical, mas sem confrontar, em qualquer momento do processo, a liberdade de escolha tanto dos termos quanto da sua combinação.

O mistério da obra, se assim podemos nos exprimir, está imbricado em todos os estágios, desde a técnica composicional até o conjunto de motivações. Esta característica da impermeabilidade da obra à análise, representada pelo 'mistério' que lhe é inerente, não impede a abordagem científica ou metódica, mas exige que esta seja atualizada, que ultrapasse a mera descrição ou a exposição das possíveis relações causais obtidas, sempre a posteriori, por um processo de dissecação, em uma lógica marcada pela obviedade, a confirmar a pressuposta perfeição da obra que examina. A abordagem científica e musicológica deve fixar como um dos seus propósitos, é nossa opinião, descobrir e elucidar os princípios a partir dos quais o compositor cria a rede aberta de possibilidades sobre a qual exercitará a sua liberdade de escolha. A prática composicional que nos esforçamos em aplicar é um sistema aberto e não determinista, mas dotada de recursos para provocar a ilusão da coerência, quando a desejamos.

É necessário esclarecer o que exatamente se quer dizer quando se afirma a afinidade e identificação com a ideologia do pensamento complexo em referência à postura composicional. No nosso caso indica, pragmática e explicitamente, uma práxis. Desde o advento do pensamento serial, e a partir dele, diversas tendências estilísticas passaram a se aplicar sobre a matéria musical recortando-a nos seus diversos e mais imprevistos parâmetros. Adotou-se para cada parâmetro uma abordagem específica, tanto ao nível dos atributos elementares quanto das funções formais. A consequência desta prática é que os parâmetros - mesmo determinados na sua escala e sucessão por um mesmo e unificador conjunto de proporções -, na maioria das vezes cada um deles em separado, passaram a ser compostos de modo relativamente independente. Somente num segundo estágio compunha-se a conjunção dos diversos parâmetros, obviamente sob a coordenação de leis gerais a partir das quais se tentava dar coerência a esta conjunção. Esta foi a prática do serialismo integral e, em muitos casos, da música experimental, obrigadas a enfrentar, ambas, a impossibilidade de materializar ao nível da percepção a organização que as erigia. Prática, também, das primeiras composições da música eletrônica, também serial integral, do mesmo modo incapaz de materializar, especialmente no plano do timbre, as pretensões que articulavam o sistema que a organizava. Herdamos desta experiência o pensamento e o instrumental, continuamente aperfeiçoado, que nos permite analisar e compor o material sonoro de um ponto de vista paramétrico. Não desconsideramos esta experiência, antes nos empenhamos em modificar o seu emprego. Conserva-se a possibilidade de uma ação profunda ao nível de cada parâmetro, mas jamais se admite abordar e organizar qualquer parâmetro de modo independente. A ideologia da prática composicional que adotamos não se 
permite fragmentar no processo composicional, sequer analiticamente, em termos dos parâmetros, as forças organizadoras da textura musical. Reiterando Morin (2007, p. 13), opera-se com 'constituintes heterogêneas inseparavelmente associadas'. A textura somente se permite abordar da perspectiva que a toma na sua inteireza e concretude. No processo composicional não há precedência de um parâmetro em relação aos outros, antes cada parâmetro se define num processo de plena interação com os demais parâmetros constituintes. $\mathrm{O}$ motivo - pois adotamos o motivo como principal articulador do discurso e da forma musical nasce com a tendência para o total cromático, com uma conformação rítmica que lhe é inerente, com uma curva dinâmica e timbre que lhe são próprios, apto a exercer funções formais, embebido das intenções estéticas daquele que o cria. $\mathrm{O}$ motivo ou tema caracteriza-se - esforçamo-nos para que assim seja - por uma extrema e inabalável coesão entre todos os seus termos.

\section{4 - A oposição natureza e cultura}

Na fundamentação das práticas composicionais é recorrente, e com frequência elevada à condição de fundamento primordial, a noção de natureza. No capítulo introdutório a The Craft of Musical Composition, escreve Hindemith (1945, p. 2): “Em Die Mastersinger lê-se, é verdade, que o compositor deve fazer suas próprias regras e então segui-las. Porém, este privilégio é assegurado apenas a um mestre - que, além disso, sabe, ou ao menos sente, que as bases de seu trabalho são providas pela Natureza".

$\mathrm{Na}$ análise da Sonata para Dois Pianos e Percussão de Bartók, Erno Lendvai encontra nas proporções formais as mesmas medidas da proporção áurea - tão cara a Leonardo da Vinci, a orientar, por exemplo, a dimensão e postura corporal do angustiado São Jerônimo no Deserto -, cuja legitimidade está em ser fórmula expressiva das reais proporções naturais, como o exemplifica com a enervação da hera. Escreve Lendvai (1983, p. 35) “As mais importantes obras de Bartók - de um ponto de vista estrutural - são a representação verdadeira do princípio da seção áurea - frequentemente da grande forma até as menores células formais". A recorrência a um sistema de proporções encontrado na natureza parece, por si só, condição suficiente para assegurar, ao menos, a perfeição formal. Bartók ele mesmo, entretanto, afasta-se do recurso à natureza como princípio fundamentador, em oposição, inclusive, a Schoenberg:

Não considero apropriado basear o caráter da música atonal no sistema da série harmônica. Embora se possa explicar pelo fenômeno da série harmônica a diversidade de caráter e o efeito dos intervalos, este ainda não oferece uma explanação satisfatória com relação ao uso livre dos doze sons (Bartók 1993, p. 458). 
Para Schoenberg (1979, p. 13):

A arte é, em seu grau ínfimo, uma simples imitação da natureza. Porém, imitação da natureza no sentido mais amplo; não mera imitação da natureza exterior, senão também da interior. Com outras palavras, não expõe simplesmente os objetos ou circunstâncias que produzem a sensação, senão, sobretudo, a sensação mesma; eventualmente sem referência ao quê, ao quando e ao como. [...] Em seu nível mais alto, a arte se ocupa unicamente de reproduzir a natureza interior.

Porém, com relação à distinção entre consonância e dissonância:

[...] procederei em minhas observações de acordo com a talvez insegura teoria dos harmônicos superiores porque o que dela se pode deduzir parece-me corresponder com o desenvolvimento dos meios da harmonia. [...] Depende somente da crescente capacidade do ouvido analisador familiarizar-se com os harmônicos mais afastados, ampliando assim o conceito de 'som suscetível de se fazer arte', que todos estes fenômenos naturais tenham um lugar no conjunto. (Schoenberg 1979, p. 15-16)

É a partir da análise do fenômeno natural da série harmônica que Schoenberg (1979, p. 16) dissolve as noções tradicionais de consonância e dissonância, a partir de então, essencialmente, de uma mesma natureza: "[...] as expressões 'consonância' e 'dissonância', a referir-se a uma antítese, são errôneas. [...] definirei a consonância como as relações mais próximas e simples com o som fundamental, e a dissonância como as mais afastadas e complexas".

Com relação à escala maior, Schoenberg $(1979$, p. 19) a explica como uma imitação da natureza, a referir-se ao modelo natural do som: "[...] intuição e combinação têm cooperado para que a qualidade mais importante do som, seus harmônicos superiores, que representamos - como toda simultaneidade sonora - sobre a vertical, seja transladada à horizontal, ao não simultâneo, ao sonoro sucessivo".

Mesmo com o extraordinário crescimento das pesquisas antropológicas, assim como das pesquisas da etnomusicologia, que trouxeram à tona uma diversidade inimaginável daquilo que denominamos música, que relativizou a prática musical ocidental, persiste o recurso às leis naturais como justificativa da adoção de determinadas práticas composicionais. É o caso, por exemplo, com o espectralismo que, da mesma forma que Schoenberg, recorrerá à série harmônica ou ao espectro sonoro para legitimar suas práticas.

Como afirma Rose (1996, p. 7): “A música espectral é singular e interessante porque sua prática responde a complexas circunstâncias físicas, como a série harmônica".

Para Murail (2005, p. 150): “[...] era uma questão de compreender as regras naturais da organização dos sons, então formalizar estas regras, fazer 
generalizações, e destas observações criar um vocabulário, então uma sintaxe, e finalmente - porque não? - expressão".

Ainda Murail (2005, p. 153), acerca do espectro:

Qualquer espectro, na verdade, cria grades, escalas (sempre de graus desiguais). O que é crucial, entretanto, é que estas grades são o resultado da ação do compositor, ao invés de uma pressuposição. [...] é melhor considerar o espectro não como uma nova espécie de grade, mas como um campo de relações possíveis em um grupo de frequências: uma concepção totalitarista, como diria um matemático. Esta concepção pode se estender a todas as manifestações do discurso musical [...] o espectro oferece, ao mesmo tempo, material e estrutura.

Tomamos o exemplo, não único, do espectralismo, por seu caráter pedagógico ao colocar em evidência a relação paradoxal entre o recurso às mais avançadas tecnologias e, concomitantemente, a adesão a uma ideologia similar àquela que sustenta Rameau em seu Traité de L'Harmonie Reduite à ses Principes Naturels. Escreve Philip Gossett (1971, p. xxii) na introdução da tradução para o inglês do Traité:

As justificativas teóricas de Rameau devem ser aceitas sob a luz da filosofia do século dezoito, como elementos na procura de princípios universais. São tentativas de reduzir todo o conhecimento a postulados centrais, encontrados na natureza, a partir dos quais todas as regras podem ser derivadas. No Traité, Rameau tenta fazer da música uma ciência dedutiva, baseada em postulados naturais, do mesmo modo que Newton aborda as ciências físicas em seu Principia

Transcrevemos a crítica abrangente e extensiva de Gossett (1971, p. xxixxii):

[...] como as explanações 'naturais' para a música tonal têm proliferado desde o tempo de Rameau, tornou-se gradualmente evidente que a música tonal como um todo não é baseada em princípios naturais e não pode ser reduzida a princípios naturais. As contradições constantes de Rameau em sua explanação da terça menor e o famoso deslocamento de Hindemith ${ }^{3}$ da terça maior para a terça menor têm muito em comum: representam esforços para impor em uma moldura natural princípios de composição que, embora relacionados à acústica, não são totalmente dependentes dela.

A rigor, com Gossett, testemunhamos que estilos e práticas composicionais extrapolam as suas referências naturais, as quais, em alguns casos - a tonalidade, a dissolução da oposição entre consonância e dissonância por Schoenberg -, são estabelecidas a posteriori. Mesmo que um fenômeno natural seja tomado como primeiro fundamento da prática composicional, o processo

${ }^{3}$ Ver Hindemith 1945, p.79. 
criativo pertence à dimensão da cultura. Esta, é nossa opinião, é que fornece ao compositor as referências estéticas e os meios para perpetuá-las ou subvertê-las.

A fundamentação do pensamento musical na natureza, ou no que a ciência nos informa ser a natureza em dado momento, inevitavelmente tem desembocado em sistemas alicerçados em princípios deterministas e, em consequência, técnicas de preordenação. É o que fica explícito em Murail (2005, p. 154):

Por meio de sucessivas aproximações - como que por meio de lentes zum estruturas de escala cada vez menor são criadas até que o menor detalhe seja alcançado. $O$ destino de cada nota individual é preordenado na composição. [...] um espectro pode, deste modo, conter formas de várias dimensões que se pode extrair sob certas condições - com certas ferramentas [...] Uma das maiores vantagens desta concepção é que a mesma técnica pode frequentemente ser aplicada a diferentes estágios de um trabalho composicional - sua forma geral, suas seções, figurações, sonoridades - e a diferentes dimensões do som musical, ou a elementos da retórica musical (negrito nosso).

Ou, ainda Murail (2005, p. 156): “[...] é obviamente necessário encontrar critérios que permitam a avaliação de sequências, mutações, taxas de renovação, oposições e similaridades. Sem uma grade que se aplique a todos os objetos manipulados, o problema não é facilmente solucionado".

Ao referir-se, de modo contundente, à experiência de uma primeira audição de 13 Couleurs du Soleil Couchant, Murail (2005, p. 165) confirma a sua confiança na predeterminação ou preordenamento: “[...] esta pode parecer uma obra claramente 'impressionista', porém, de fato, é uma composição altamente predeterminada e calculada".

No mesmo sentido, em seu artigo sobre os pós-espectralistas Kaija Saariaho, Philippe Hurel e Marc-André Dalbavie, Pousset (2000, p. 77) identifica um novo determinismo: "Entramos em uma fase de lenta construção musical, onde a adoção do princípio da causalidade é a manifestação mais clara. Além disso, um novo determinismo adentrou o processo composicional".

Citamos a constatação de Morin (2007, p. 42-43), que lança luzes sobre esta postura: "Conforme se valorize o objeto, valoriza-se neste impulso o determinismo. Mas se o sujeito é valorizado, então a indeterminação torna-se riqueza, fervilhar de possibilidades, liberdade!" Não é de estranhar, pelo contrário, o determinismo que domina as estéticas onde o som e suas propriedades físicas são sublimados. Ao afastar o sujeito, ao tentar afastar o imprevisível, a incerteza, o desconhecido e o indeterminado que este representa, não resta mais do que o determinismo, ação e processo pelos quais a objetividade - de extrema pobreza se entregue a si própria - se manifesta. Evidentemente, tem-se que considerar o som e suas propriedades, mas submissos e como 
instrumentos disponíveis para o sujeito, única entidade capaz de manipulá-los e de conferir-lhes sentido.

A preordenação implica em um problema de ordem ética: a questão da responsabilidade do compositor quanto à estética de sua própria obra. Com a preordenação, transfere-se a responsabilidade para um sistema reificado, tem-se como consequência o conformismo e quase desprezo pelo produto, muitas vezes efêmero, gerado pelo sistema autoimposto, com a consequente supervalorização do sistema mesmo. O compositor eleva-se (ou desce) à condição de criador de um sistema auto-organizador ou, similar, de um algoritmo. A obra é mero acidente a validar o sistema ou o algoritmo que a gerou. O sujeito é anulado no decorrer do processo composicional.

Para que se evite o equívoco, para que não se pense que estamos empenhados em apontar os pontos fracos de Schoenberg ou dos espectralistas, em nossa crítica à preordenação, à fundamentação no fenômeno natural e ao consequente determinismo na criação musical, esclarecemos que, assim pensa o autor, tanto um como os outros se elevam numa prática que está muito além de suas reflexões teóricas. É válida e extensiva, tanto para Schoenberg quanto para os espectralistas, a observação de Gossett (1971, p. xxi-xxii) acerca de Rameau:

[...] devemo-nos manter cientes de que a inadequação de muitas das explanações de Rameau nem sempre interfere com o brilho de suas teorias. [...] Que Rameau não seja completamente bem sucedido não nos impede de reconhecer os enormes avanços na teoria da música tonal decorrentes de seus trabalhos.

Debussy (1989) aponta para outra direção no posicionamento frente à dualidade natureza e cultura. Manifesta-se por seu alter ego, Monsieur Croche:

A música é um total de forças esparsas ... Faz-se dela uma canção especulativa! Prefiro as poucas notas da flauta de um pastor egípcio, ele colabora com a paisagem e ouve harmonias desconhecidas pelos tratados dos senhores... Os músicos só ouvem música escrita por mãos hábeis, nunca aquela que está inscrita na natureza. Ver o dia nascer é mais útil que ouvir a Sinfonia pastoral. De que serve a sua arte quase incompreensível? Será que os senhores não deveriam suprimir dela as complicações parasitas que a aproximam, na engenhosidade, de uma fechadura de cofre-forte?... Estão marcando passo porque não sabem que a música obedece a leis bárbaras e desconhecidas ... (Debussy 1989, p. 52).

Debussy distingue a 'música escrita por mãos hábeis' daquela 'inscrita na natureza'. Insere nesta distinção uma escala de valor. Sonha com a integração da cultura e da natureza na figura do pastor egípcio, contra a 'canção especulativa'. É o equilíbrio entre cultura e natureza o que deseja Debussy, ao sugerir a supressão da engenhosidade ao estilo 'fechadura de cofre-forte', ao mesmo tempo em que chama a atenção para as 'leis bárbaras e desconhecidas' que regem 
a música. Bárbaras e desconhecidas por se situarem na origem mesma da condição humana. Acerca da Sonata de Paul Dukas: “O Sr. P. Dukas sabe o que a música contém; ela não é unicamente uma sensação brilhante e sonora que diverte o ouvido até o enervamento: compreensão fácil onde se reúnem tantas músicas que se pensa serem ... diferentes ..." (Debussy 1989, p. 33). Debussy condena a especulação dominada pela engenhosidade, as "complicações parasitas", mas também não o satisfaz a sensação brilhante da sonoridade que, sensação quase pura, "diverte o ouvido". Debussy argumenta pela preservação do mistério da criação.

Stravinsky (1977, p. 27) vê a música situada não no plano da natureza, mas como organização consciente dos elementos sonoros:

Tomarei o exemplo mais trivial: o do prazer que se sente ao escutar o murmúrio da brisa nas árvores, o sussurro de um riacho, o canto de um pássaro. Tudo isso nos agrada, diverte, encanta. Podemos mesmo dizer: "Que bela música!" Naturalmente, falamos apenas em termos de comparação. Porém, comparação não é premissa. Estes sons naturais nos sugerem a música, porém eles mesmos ainda não são música. Se temos prazer com estes sons ao imaginar que expostos a eles nos tornamos músicos e mesmo, momentaneamente, músicos criativos, devemos admitir que enganamos a nós mesmos. Eles são promessas de música; é preciso um ser humano para retê-los: um ser humano sensível às muitas vozes da natureza, sem dúvida, porém que sinta, além disso, a necessidade de pô-las em ordem e que seja dotado com uma aptidão muito especial para esta tarefa. Em suas mãos, tudo que considerei como não ser música tornar-se-á música. Disto concluo que os elementos sonoros tornam-se música apenas em virtude do seu ser organizado, e que tal organização pressupõe um ato humano consciente.

Na sua definição de arte, ressaltam os conceitos de método, aprendizagem e invenção, nenhuma referência à natureza: “A arte, em verdade, é uma maneira de moldar obras segundo certos métodos adquiridos pelo aprendizado ou pela inventividade. E os métodos são os caminhos justos e predeterminados que asseguram a exatidão de nossa ação" (Stravinsky 1977, p. 28). Ao tratar, mais especificamente, do fenômeno musical:

No que me diz respeito, somente começa a interessar-me o fenômeno musical enquanto uma emanação do ser humano integral. Quero dizer, do ser humano de posse de todos os recursos de seus sentidos, de suas faculdades psíquicas e das faculdades de seu intelecto.

Somente o ser humano integral é capaz do esforço de alta especulação que deve, neste momento, atrair nossa atenção.

Porque o fenômeno musical não é senão um fenômeno de especulação (Stravinsky1977, p. 31).

A reafirmar este pensamento: “Em seu estado puro a música é especulação livre" (Stravinsky 1977, p. 53). 
Aproxima-se Stravinsky do pensamento de Lévi-Strauss (2004). Este, na distinção entre pintura e música, expõe os respectivos vínculos: "[...] à diferença da cor, que é um modo da matéria, a tonalidade musical é um modo da sociedade" (Lévi-Strauss 2004, p. 39). Com relação à música mesma:

[...] a natureza produz ruídos, e não sons musicais, que são monopólio da cultura enquanto criadora dos instrumentos e do canto. [...] os sons musicais não existiriam para o homem se ele não os tivesse inventado.

Portanto, é apenas a posteriori e, digamos, de modo retroativo, que a música reconhece aos sons propriedades físicas e seleciona algumas delas para fundar suas estruturas hierárquicas [...] é a cultura que já estava diante dela, mas sob forma sensível, antes que, por meio da natureza, ela o organizasse intelectualmente. O conjunto sobre o qual ela opera é de ordem cultural, o que explica o fato de a música nascer inteiramente livre dos laços representativos (Lévi-Strauss 2004, p. 42).

A oposição natureza e cultura encarna, grosso modo, duas claras tendências - opostas e excludentes num primeiro momento - da composição musical: de um lado aqueles que recusam à música a potencialidade para a significação, e desenvolvem sua obra encantados com o som propriamente dito, convencidos da suficiência das relações exclusivamente sonoras. A música lhes aparece como uma entidade radicalmente isolável, cuja legitimidade se afirma absolutamente independente do meio social. A natureza das relações musicais é a mesma da matéria inorgânica. A função é metalinguística. Permitimo-nos a digressão acerca do emprego do conceito de inorgânico na composição musical. Reencontramos este conceito no texto de Thurlow (2010), Métaboles as a Fork in the Road: Twin Paths in Dutilleux's Later Music. Para Thurlow, Métaboles representa na obra de Dutilleux um novo caminho que se abre na relação entre dois paradigmas opostos, expressos nos conceitos de 'orgânico' e 'inorgânico'. Este novo caminho caracteriza-se:

[...] pela descontinuidade e alterações súbitas, por um papel primordial da textura, timbre e (consequentemente) sonoridade, e associado com imagens e processos físicos não-humanos. De alguns modos, este caminho prefigura o trabalho dos espectralistas. Este modo 'inorgânico' de composição pode ser confrontado a uma contraparte 'orgânica' representada pela fascinação de Dutilleux com a mudança gradual, similaridades, memórias e premonições, que é predominante nas sinfonias, mas que também permanece em seções do último trabalho (Thurlow 2010, p. 485) (negrito nosso).

Ainda mais, a tratar da emergência do 'argumento inorgânico', escreve Thurlow (2010, p. 492): "Métaboles apresenta a primeira aparição de pleno direito de um 'argumento' na música de Dutilleux que pode ser caracterizado como alheio, glacial, inorgânico, não-expressivo, não-discursivo e mesmo, em certo 
sentido, inumano. [...] o argumento inorgânico em Dutilleux é associado ao sublime" (negrito nosso).

No outro extremo, a retomar nosso pensamento, situam-se aqueles que reconhecem na linguagem musical a plena potencialidade para a representação simbólica e a significação. A música encontra o seu sentido como objeto posto a intermediar a relação do compositor com o meio social, de onde o compositor herdou os meios de expressão sobre os quais constituiu o seu próprio discurso, este, ele mesmo, força renovadora da linguagem herdada. A função é expressiva. Entre um extremo e outro há uma infinidade de gradações, e o posicionamento de cada compositor se define, na realidade, pela dominância de uma tendência ou outra, pois as preocupações com os signos musicais eles mesmos assim como, por outro lado, com as suas aptidões para a significação, constatamos, jamais estão completamente ausentes, independente da posição assumida ou posteriormente atribuída.

Murail (2005) situa a si mesmo na dominância da tendência à natureza ao declarar: "Não acredito que a música expresse significado. Termos como 'linguagem', 'escrita', 'mensagem', 'estrutura', etc. apenas podem ser utilizadas como analogias dúbias com a linguagem falada" (p. 149). Entretanto, a contradizer-se, no mesmo texto, escreve que "Ignorar os resultados aurais do ato composicional é, para mim, uma recusa a se comunicar. E, se os compositores não se comunicam, não é surpresa que as salas de concerto estejam vazias" (p. 161).

Irônica e equivocadamente, Stravinsky constituiu-se numa referência da tendência à natureza, à prática da composição musical predominantemente voltada para a exploração das propriedades dos termos sonoros e suas relações, ao afirmar que "a música em si não significa nada" (1984, p. 91). A afirmação de Stravinsky não só é contradita pela sua própria visão da música como "um elemento de comunhão" (Stravinsky 1977, p. 137), mas, de modo ainda mais incisivo, por sua prática composicional. Retemos o exemplo denotativo de Petrushka, modelar, onde o detalhamento da caracterização atribui a cada personagem - definindo-o e expondo vínculos insuspeitados - um intervalo musical que lhe é próprio. A terça-maior identifica o sensual e perverso Mouro. A segunda-maior a Bailarina fascinada pela esplendida aparência do Mouro, a quem seduzirá. O trítono a Petrushka, a quem foi dado mais sentimentos e paixões humanas do que aos outros. O movimento intervalar para o mesmo Fá sustenido prenuncia a união da Bailarina e do Mouro. Os distintos movimentos intervalares do Mouro e Petrushka, a partir de um mesmo Sol sustenido, antecipa a divergência fatal que lhes é reservada. A obra de Stravinsky, podemos afirmar, em suas diversas fases, é carregada de uma densa cadeia significativa, que extrapola os limites do domínio musical, ou, melhor dito, das relações exclusivamente sonoras. É inegável que na sua obra se alcança um equilíbrio 
ímpar entre o domínio da dimensão cultural e as preocupações com a sintaxe propriamente musical. Assim o demonstra a sua visão da técnica musical como criação e imagem do 'homem por inteiro'.

\section{5 - O signo musical}

Há, assinalemos, distinção fundamental entre o signo musical e o signo de que se serve a linguagem articulada. Enquanto neste último o significado cola, funde-se ao signo inexoravelmente e de um modo que ultrapassa o discurso, constituindo-se esta relação entre signo e significado numa propriedade do coletivo, o signo musical tem a propriedade de se despir, sem que reste qualquer traço, de todo o complexo de referências e significados ao qual se permitiu vincular em uma determinada obra. O laço representativo que une um signo musical a seu significado não é dado a priori, tem que ser construído no decorrer da própria obra que o institui. Uma vez determinado, a sua vigência é circunscrita à obra onde foi estabelecido. Pode-se até, excepcionalmente, efetuar o transporte do mesmo laço para outro movimento ou obra, a citá-lo, mas, ainda assim, a vigência será sempre rigorosamente circunscrita, jamais assumirá um caráter universal, como ocorre com a linguagem articulada, em relação ao grupo social que a possui. Em música, o vínculo entre signo e significado é efêmero. $\mathrm{O}$ signo musical, a reiterar Lévi-Strauss (2004, p. 42), sempre se apresenta, nos primeiros impulsos do processo criativo, "inteiramente livre dos laços representativos", destituído de todo e qualquer vínculo com o significado. $\mathrm{O}$ signo musical é essencial e fundamentalmente apto à ressignificação.

Encontramos em Menezes (1996, p. 29) a constatação de que:

[...] é a recusa da linguagem [...] que irá caracterizar acima de tudo a música concreta. [...] A lógica do percurso concreto é-nos absolutamente clara: se linguagem implica seleção; se seleção implica código, e código, significação, é somente por meio de uma recusa total do dado linguístico que se poderá banir inelutavelmente a significação do contexto musical.

A música concreta não parte do signo musical, é nosso entendimento, mas da transformação de qualquer signo in natura em signo musical. Sua primeira providência é então a de eliminar do signo elegido toda e qualquer referência, reduzindo-o a um fenômeno essencial e puramente sonoro. Neste processo, embora não se dê conta disto o próprio Schaeffer, o que faz a música concreta não é destituir o signo musical da sua potencialidade para a significação - seja pela repetição, variação ou transformação -, mas dotar um signo originalmente não musical das características do signo musical, "inteiramente livre dos laços representativos", possuído da volatilidade que permite ao signo musical despir- 
se de toda e qualquer referência anteriormente atribuída para estar a cada retomada do processo criativo plenamente apto para a ressignificação, pronto a conduzir e materializar o permanente processo de afirmação dos valores da convenção no âmbito próprio da linguagem musical, em suma, apto a participar e contribuir com o processo de constituição do discurso musical. Não é este o pensamento de Schaeffer, seguidor do exemplo dos grandes naturalistas, como o declara, quando escreve: "Há séculos a música é expressão, ou seja, linguagem. Bruscamente, a música concreta traz um elemento de ruptura, e opõe à linguagem um objeto que não se exprime mais" (Schaeffer 1952, p. 114). O signo musical, reafirmamos, é, na sua origem, inexpressivo, embora apto para a expressão. Seu significado se constrói no decorrer da obra e somente se sustenta nos limites desta. A construção deste significado, embora desencadeado pelo compositor, é dependente do processo complexo de apropriação pelo coletivo. Há, sem dúvida, em Schaeffer o equívoco, aparente em seu discurso contraditório, de considerar o signo musical intrinsecamente expressivo, ao menos até o advento da música concreta. Não o é! Quando nos defrontamos com o signo musical, no esforço de ordenação das forças envolvidas no processo criativo, encontrámo-lo destituído de significado. Este é criado e se materializa

pela ação, quando bem sucedida, do compositor. É distinta a experiência com a linguagem articulada, tomada de empréstimo da coletividade, já na sua origem inundada de sentido e significação precedentes e transcendentes ao discurso. Com a linguagem articulada, parece-nos, encontramos processo semelhante ao desenvolvido por Schaeffer com a música concreta: o escritor, no processo de constituição de seu próprio discurso, depura o signo linguístico para lhe conferir a maleabilidade necessária para a construção de seu próprio discurso, de seu universo simbólico particular. Enfim, parece-nos, Schaeffer, a dar sentido a suas contradições, empenha-se em compor um novo e muito mais amplo conjunto de elementos musicais fundamentais, aberto a qualquer matéria sonora, e a torná-lo apto, no esforço de esvaziar os seus elementos de toda e qualquer referência original, a integrar, pelo processo típico da ressignificação, os processos de construção característicos da linguagem musical. É o que também constata Menezes (1996, p. 23) quando escreve: “[...] Schaeffer reconhecerá, mesmo após ter almejado a anulação da linguagem no seio das realizações da música concreta, o caráter eminentemente linguístico das manipulações dos ruídos que ela efetua".

\section{6 - Entre a natureza e a cultura, onde nos situamos?}

A oposição natureza e cultura não alcança a infinidade de matizes que se interpõe entre uma e outra. Mas pode nos servir como polos a orientar na distinção das diversas tendências estéticas. É útil, aqui, num processo de quase 
autoanálise, para orientar o próprio autor a determinar o seu sítio. Posicionar-se na convicção de que a música, enquanto sistema, em todos os seus aspectos e constituintes, é predominantemente cultural, como é o nosso caso, implica, para a efetiva percepção das relações instauradas, a admissão de que a apreciação musical - como toda linguagem, na sua sintaxe e, sobretudo, redes de significação - resulta de um fenômeno de aprendizagem, que nos torna aptos a decifrar as convenções postas em jogo. Referimo-nos, especialmente, não às convenções das práticas composicionais, à aridez dos objetos sonoros considerados em si mesmos, mas às convenções que fazem do fato musical um fato significativo, que fazem submergir o fato musical na complexa rede das relações sociais. A música, quer queira quer não, é fato social, desencadeadora de complexos e diversificados fenômenos de interação. Enquanto tal transporta uma mensagem compreensível, em razão da qual lhe são reconhecidas indubitáveis funções sociais, inclusive a função especulativa. Cada membro de um determinado grupo ou subgrupo social é capaz de julgar, em relação à música produzida no seu meio, a propriedade com que estas funções sociais são exercidas.

É sobre os conceitos de convenção e aprendizado, a possibilidade da implementação das funções denotativas e conotativas, que este autor se apoiará na construção das relações entre texto e música, e mesmo da orientação estética subjacente à elaboração motívico-temática das obras exclusivamente instrumentais. Ser a música nascida inteiramente destituída de laços representativos, como o afirma Lévi-Strauss (2004, p. 42), no sentido de laços perenes e universais, como o entendemos, coloca para o compositor o desafio de construir a cada obra, e por ela mesma, um quadro simbólico resultado de uma combinação única e não generalizável entre signo musical e significado. Diferentemente da linguagem articulada, onde reencontramos sempre os mesmos signos, ou onde a renovação linguística é seguida do enrijecimento da relação do signo com o significado, em que é possível estabelecer um léxico como referência segura para a decodificação da mensagem, a volatilidade do signo musical impõe ao compositor a tarefa de reconstruir a linguagem musical - seu conjunto de signos e os respectivos vínculos com os significados então atribuídos - a cada obra. Pode-se afirmar que em música não há uma língua, mas unicamente discurso. Mesmo quando nos referimos, retrospectivamente, à tonalidade, a ignorar inadvertidamente o seu processo histórico, a ideia de estilo associada aos traços peculiares de cada compositor é tão mais forte e dominante, que é improvável a confusão na identificação estilística dos compositores - que ouvinte educado equivocar-se-á no reconhecimento das diferenças estilísticas de Brahms e Bach ou Rossini, Mozart e Mahler? Entretanto, os princípios gerais consolidados tanto na teoria da música quanto na análise musical - atribuídos retrospectivamente são tão frágeis, não consensuais e distanciados do fenômeno em si, por sua pretensão à generalidade, que agrupar estes mesmos compositores 
sob o conceito genérico da tonalidade somente é válido sob uma perspectiva pedagógica, para ressaltar afinidades coletivas, em detrimento das gradações que caracterizam as transições e as diferenças de estilo. Não se pode ignorar a dinâmica do pensamento musical ocidental, em todos os períodos, vivificado, sempre e unicamente pelo discurso, na constituição do estilo individual. Diferentemente da língua articulada em que as normas são dadas a priori, em música, assim como nas artes visuais, as normas somente são estabelecidas $a$ posteriori, a partir da análise do conjunto de obras e estilos individuais que o grupo social escolhe para se fazer representar.

\section{7 - Léxico, signo e significado musical}

O conceito de léxico é fundamental, do nosso ponto de vista, para se compreender as características que distinguem a linguagem articulada e a linguagem musical, e afastar de vez as tentativas de interpretação de uma pela outra. Encontramos, por exemplo, documentadas, inumeráveis figurações com a interválica, arriscamo-nos a dizer, possível de ser referenciada a escalas maiores desde os primórdios da idade média até, por exemplo, a música de Ferneyhough. ${ }^{4}$ Mas destes inumeráveis casos, não é possível extrair um conteúdo comum, permanente e geral que permita a dicionarização. Esta é a regra geral com os termos musicais. A cada emprego, a figuração se apresenta inteiramente renovada, inesgotável na sua potencialidade para a significação, plenamente apta a atuar de modo singular na composição do estilo individual. Porém, por estas qualidades mesmas, resistente e avessa à ação lexicográfica, ao contrário dos termos da linguagem articulada nascidos e destinados à integração ao léxico.

Entretanto, apesar do caráter único da obra, da volatilidade do signo musical, embora o processo de constituição da relação signo e significado musical seja do domínio de um grupo especializado, o dos músicos, a consumação do processo transfere-se para o domínio do coletivo. Lévi-Strauss (2004, p. 37) observa "o fato de a música ser uma linguagem - por meio da qual são elaboradas mensagens das quais pelo menos algumas são compreendidas pela imensa maioria, ao passo que apenas uma ínfima minoria é capaz de emiti-las". Admitimos que a compreensão da mensagem musical "pela imensa maioria" é possível e se realiza exatamente porque é peculiar à linguagem musical esta transferência do processo consumado da constituição de uma relação específica entre signo musical e significado para o domínio do coletivo. Assim como é peculiar à linguagem musical que a relação consumada seja específica e não

\footnotetext{
${ }^{4}$ Veja, por exemplo, o compasso 29, 3/8, última semicolcheia, de INTERMEDIO alla ciaccona, para violino solo, London: Edition Peters, 1986.
} 
passível de universalização. A retomar nosso pensamento, a tipologia destas relações não permite a constituição de um léxico, embora, na sua singularidade, seja compreensível "pela imensa maioria". Esta compreensão é mediada pela função social.

A retomar a oposição natureza e cultura, a nossa orientação é convicta no sentido do polo cultural, em ostensiva recusa a qualquer determinação estabelecida a partir dos dados naturais ou que resulte da sua análise. "A arte dos sons é completamente cultural", como o escreve Lévi-Strauss (1997, p. 83). Nosso trabalho composicional apoia-se na confiança no valor da convenção. Esta, assim procuramos estabelecer na prática, será acordada a cada obra, embora, em alguns casos especiais, como acontece em Três Canções sobre Poemas de Fernando Pessoa, deste autor, alguns signos musicais - chamados a exercer a função unificadora, a afirmar a ideia de ciclo - serão disseminados, com toda a sua carga semântica e aptidões funcionais, pelas três canções do ciclo.

\section{8 - Percepção dos processos e relações postos em jogo na composição musical}

Preocupa-nos a percepção dos processos desencadeados pelo compositor quando da evolução fenomênica da obra musical, no seu intrínseco desenrolar temporal. Argumentamos que a superfície dos eventos sonoros deve ser capaz de informar dos processos desencadeados para a sua materialização. Que estes processos, se têm uma efetividade real, sejam reconhecíveis no fenômeno mesmo da percepção musical. É falsa, ilusória e de resultados duvidosos a análise que se detêm na imagem atemporal e rigidez mórbida da partitura, da escrita musical, ferramenta ainda essencial para o registro e, consequentemente, a execução musical, mas de todo inadequada para a análise por subtrair da experiência sensória o seu traço mais essencial, o de ser a música uma arte que transcorre no tempo. ${ }^{5} \mathrm{Na}$ consideração do valor perceptivo do emprego da simetria na organização do ritmo, a condenar a predominância do caráter visual em detrimento do caráter auditivo na análise musical (ou anti-musical!) a partir da partitura, Grisey (1987, p. 242) faz crítica semelhante: “Ou ao menos isto seria,

\footnotetext{
${ }^{5}$ Nos seminários de análise musical, no transcorrer do meu doutorado na UFRGS, os orientadores - Antônio Carlos Borges Cunha e Celso Giannetti Loureiro Chaves - estabeleceram a metodologia da análise baseada, primeiramente, na experiência auditiva. A cada aluno era solicitado que produzisse um texto analítico com base na experiência direta com a obra musical, com a sua linguagem sonora. Em uma segunda etapa, era solicitado que se confrontasse o primeiro trabalho com as observações feitas, em um segundo momento, a partir da análise da partitura, então disponibilizada. O que pude observar é que, para nossa felicidade, esta experiência permitiu que nos libertássemos de uma prática de "analfabeto", e possibilitou-nos ascender a uma inédita apreensão da obra na sua totalidade. Ao invés de nos determos na "coleta" de grupos de alturas, células rítmicas, jogos de timbres, e demais "sonemas", a análise fundada na experiência auditiva nos colocou frente a frente com as relações verdadeiramente significativas.
} 
uma vez mais, o interesse apenas do especialista que lê [mas não ouve] uma partitura!" Como aconteceu com a linguística, que fez da fala o centro de seu interesse, e, a partir de então, conseguiu avanços extraordinários na nossa compreensão do fenômeno da linguagem, também em música, a seguir o exemplo, deve-se procurar focar o interesse nos modos como selecionamos e organizamos concretamente o fenômeno sonoro como meio de expressão, mesmo quando reduzida à experiência primária do encantamento pelo som propriamente dito. Fazemos nossa a observação de Menezes (1996, p. 36) na crítica retrospectiva à aplicação da técnica serial na organização do timbre na música eletrônica: "Que seja sempre à percepção que dirigimos nossas mensagens, sejam essas o produto de uma operação ostensivamente concreta ou, ao contrário, o resultado de uma elaboração totalmente abstrata, parece-nos nesse entretempo bem evidente". A prioridade que concedemos ao fenômeno sonoro em si, faz-nos compartilhar e adotar, como princípio fundamental, o primeiro postulado de Schaeffer (1967, p. 29), da 'primazia do ouvido', em defesa de uma 'escuta essencialmente fenomenológica'. Quanto ao terceiro postulado de Schaeffer, 'buscar uma linguagem', não somos sequer capazes de conceber outra possibilidade.

\section{9 - Aspectos da técnica composicional}

A atividade composicional pressupõe a adoção de um conjunto de premissas fundamentais na determinação da própria prática e, por consequência, do estilo. Esforçamo-nos por nos fazer conscientes destas premissas, a maioria delas herdadas, e das consequências ao adotá-las. Das reflexões já feitas, é previsível que o critério fundamental e primeiro que utilizamos na escolha das premissas é exclusivamente de ordem cultural. A sua legitimidade não está na referência ou vínculo aos dados naturais, mas no pertencimento a uma dada cultura, a um conjunto de valores estéticos que tem em alta conta a herança legada pela tradição. Tomamos o fato sonoro como uma totalidade, como um fenômeno complexo, formado por 'constituintes heterogêneas inseparavelmente associadas'. Somente as desmembramos, artificiosamente, em benefício do esclarecimento do método.

Procederemos à abordagem de alguns aspectos da técnica musical que são generalizáveis apenas ao nível das obras que serão consideradas mais adiante. Em relação à organização das alturas, no plano melódico, é determinante a 'elaboração motívico-temática'. Esta, entretanto, é articulada tanto pelo 'princípio da complementaridade cromática' quanto, a incutir-lhe direcionalidade, pelos 'eixos cromáticos'. 


\section{1 - O princípio da complementaridade cromática}

Consideremos, em primeiro lugar, o 'princípio da complementaridade cromática'. Já o encontramos, plenamente desenvolvido, na denominada fase atonal de Schoenberg. Não se pode deixar de comentar, anotada em texto de 1923, a resistência de Schoenberg (1984, p. 210-211) ao termo atonal: "Considero, sobretudo, que a expressão 'música atonal' é muito infeliz - equivale a denominar voar como 'a arte de não cair', ou nadar 'a arte de não afogar'. [...] Além disso, a expressão atonal não pode ser tomada a sério como uma expressão, pois não foi assim que surgiu. Um jornalista derivou-a por analogia de amusisch [amusical], como uma forma de caracterização hiperagressiva [...] Porém, as expressões na estética devem ser melhor colocadas, não devem originar-se da sátira". Retomemos a linha de nosso pensamento: $O$ "princípio da complementaridade cromática' é a tendência - não mais do que a tendência - à ocorrência de todas as alturas do total cromático, sem que, necessariamente, seja imposto um ordenamento fixo à sucessão das alturas ou a referência a classes de alturas. O conceito expressa prática oposta, por exemplo, às de Boulez, e daquela da música serial de Stockhausen e Berio, no que se refere à organização das alturas. Estes compositores partem do total cromático, organizado na forma de uma série, e por procedimentos diversos subvertem este total cromático em sucessões de alturas irredutíveis, em maior ou menor grau, às possibilidades de combinação dedutíveis da série inicial. O exemplo mais notório e, ao mesmo tempo, esclarecedor é a técnica da multiplicação de frequências ${ }^{6}$ idealizada por Boulez, exaustivamente aplicada no Le marteau sans maître. ${ }^{7}$ Ao contrário, no nosso caso jamais partimos do total cromático. Dirigimo-nos a ele ou por ele, como o faz um navegante por meio de sua bússola. O 'princípio da complementaridade cromática' é, na sua essência, um princípio orientador. Os primeiros compassos do op. 19 de Schoenberg (Exemplo 2) ilustram o princípio:

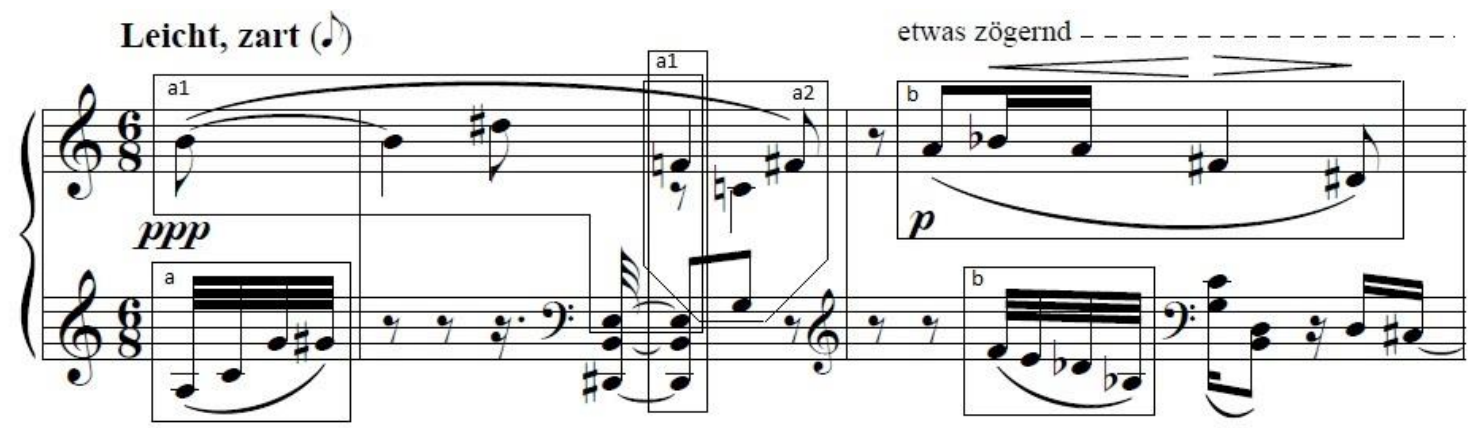

Exemplo 2: Análise da ocorrência do 'princípio da complementaridade cromática' no primeiro dos Sechs Kleine Klavierstücke, de Schoenberg

${ }^{6}$ Ver Boulez, A música hoje, p. 38-39.

${ }^{7}$ Ver Koblyakov, Pierre Boulez: a world of harmony, p. 3-7 
A primeira frase é composta por células derivadas por variação do conjunto inicial de alturas "a". Cada célula tem em comum, esquematicamente, dois intervalos de semitom sucessivos. O princípio da variação está na evolução, por semitom, do intervalo inicial de terça menor em "a", passando pelo intervalo de terça maior em "a1", até o intervalo de quarta justa em "a2". A célula "a" compõe-se, então, de dois intervalos fixos, de semitom, e um intervalo variável na razão de um semitom.

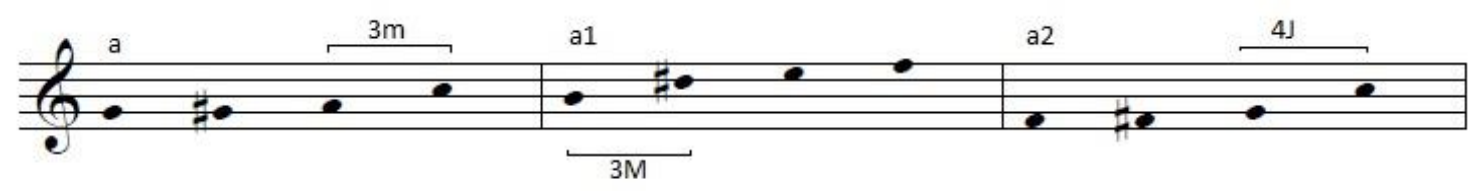

Exemplo 3: Representação esquemática das alturas das células que constituem a primeira frase do primeiro dos Sechs Kleine Klavierstücke op.19, de Schoenberg. "a1" e "a2" são derivados de "a", mantendo-se constantes os dois intervalos de semitom, e fazendo evoluir, na razão do semitom, o intervalo de terça menor para o de quarta justa

"a" é exposto melodicamente, "a1" melódica e harmonicamente, e "a2", permitimo-nos assim classificar, diagonalmente. $\mathrm{O}$ "princípio da complementaridade cromática' organiza a interação das várias células, interação que tende ao total cromático.

O dodecafonismo, assinalemos, é um caso específico da complementaridade cromática, em que a tendência é substituída pela obrigatoriedade da exposição do total cromático, e onde os intervalos e alturas são constrangidos a uma ordem fixa, consolidada na série. Assim se expressa Schoenberg (1984, p. 91), em referência à Serenade op.24, ao comentar a evolução de seu método:

As variações subsequentes utilizam inversões e retrógrado das inversões, diminuições e aumentações, canons de várias espécies, e alterações rítmicas para diferentes compassos - em outras palavras, todas as ferramentas técnicas do método [dodecafônico] estão aqui, exceto a limitação a somente doze sons distintos (negrito nosso).

A análise de Schoenberg, observemos, aplica-se com perfeição ao Terceiro Quarteto de Bartók, como o mostraremos logo adiante.

A consideração de Bartók (1993, p. 455-456), em texto de 1920, intitulado O Problema da Nova Música, esclarece ainda mais a prática atonal de Schoenberg assim como a fundamentação do 'princípio da complementaridade cromática':

Porém, a mudança de direção decisiva para a atonalidade começou apenas quando se sentiu a necessidade pela igualdade de direitos de cada um dos doze sons de nosso modo dodecafônico: quando se fez o esforço para evitar o arranjo 
dos doze sons de acordo com certos sistemas escalares ou atribuir a cada um dos sons maior ou menor valor em conformidade com este arranjo, de modo que se pode utilizar cada um dos sons em qualquer combinação opcional, tanto horizontal quanto verticalmente, não reportável a qualquer sistema escalar. É verdade que certos sons na combinação também ganham, por este procedimento, uma relativa predominância; esta diferença de importância, entretanto, não é baseada em um certo modelo de escala, antes é o resultado da combinação ocasional; assim como cada um dos membros, nos grupos combinados, tem um valor e intensidade diferentes em relação uns aos outros. As possibilidades de expressão são acrescidas em grande medida, incalculável por ora, pelo livre e igual tratamento dos doze sons (negrito nosso).

É característico do que denominamos complementaridade cromática o 'livre e igual tratamento dos doze sons', a considerar a exploração das possibilidades de predominância ocasionais em função das necessidades expressivas e, por consequência, formais.

Em Bartók, encontramos o 'princípio da complementaridade cromática' a organizar as várias linhas das texturas polifônicas, assim como as interações que resultam na diagonalidade ${ }^{8}$. Exemplo notável da aplicação do 'princípio da complementaridade cromática' encontramos na utilização que faz Bartók do 'modo dodecafônico' na composição do tema principal que abre o seu Terceiro Quarteto de Cordas:

\section{3rd String Quartet}

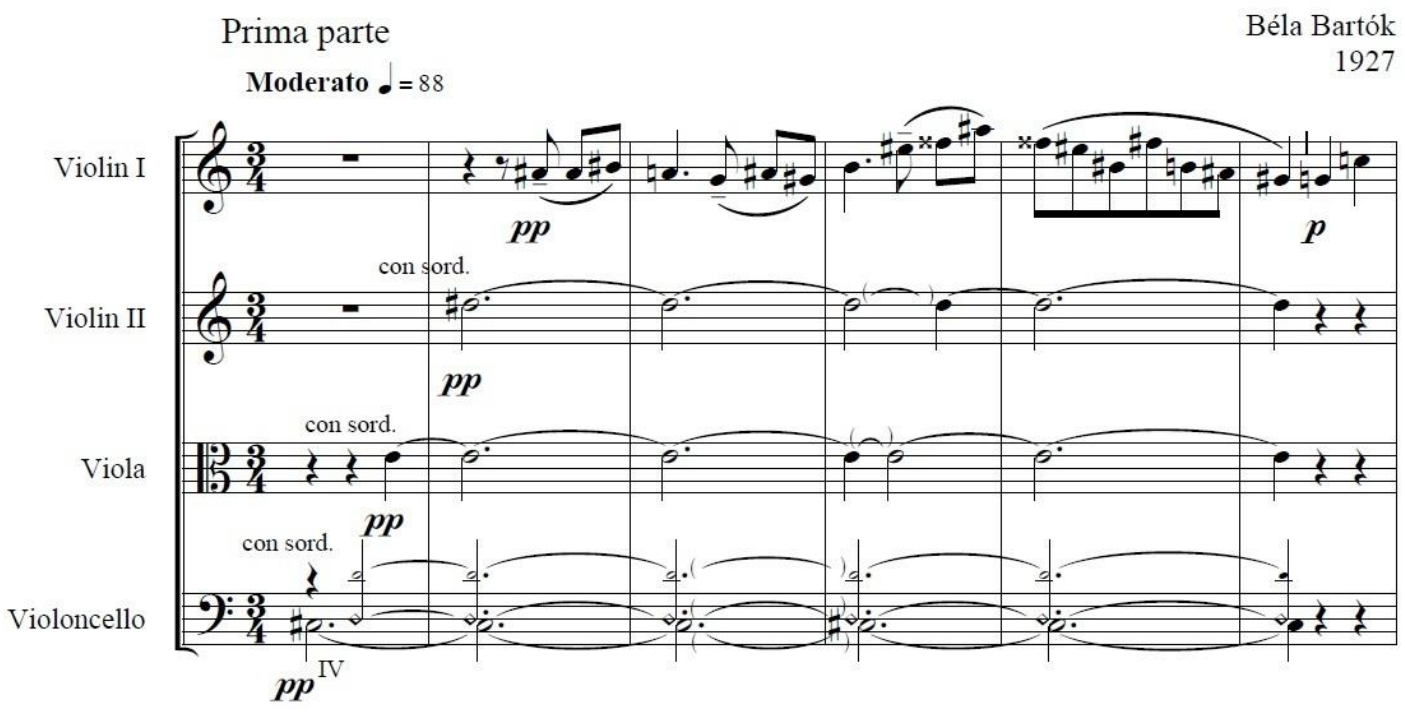

8 A diagonalidade - como ilustraremos com exemplos do próprio Bartók - resulta da gradual evolução de uma textura que impressiona pelo movimento melódico para uma textura que impressiona pela verticalidade ou formação harmônica. Exemplo seminal encontramos no movimento melódico que leva à formação do acorde de dominante sobre o pedal da tônica nos segundo e terceiro compassos da Tocata e Fuga em Ré menor, BWV 565, de Bach. 


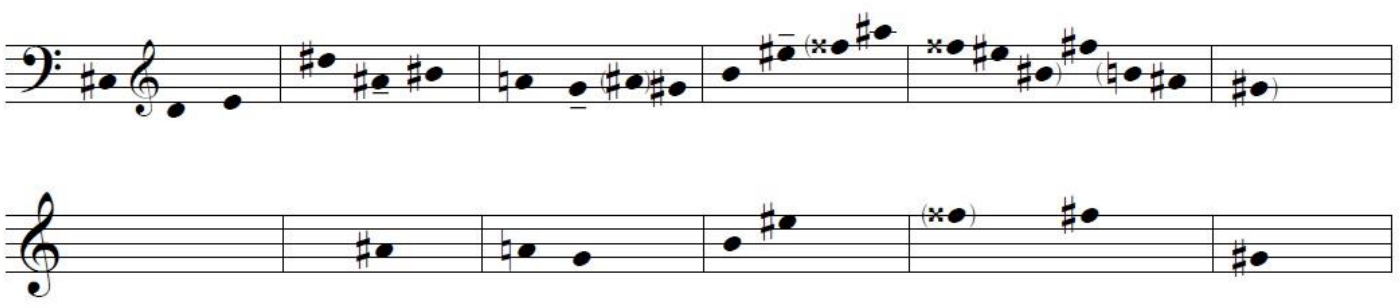

Exemplo 4: Emprego do 'modo dodecafônico' por Bartók

No segundo sistema do Exemplo 4 estão discriminadas as alturas, com as reiterações postas entre parênteses. Com exceção do Fá dobrado sustenido no quinto compasso, todas as reiterações ocorrem nas partes fracas do compasso. Embora a métrica seja 3/4, com o recurso do tenuto, a linha melódica do primeiro violino ocorre de fato na métrica 6/8. Esta articulação rítmica faz emergir outro extrato cromático - demarcado pelos tempos fortes da métrica 6/8, conforme explicitado no último sistema deste exemplo - composto das sete alturas do intervalo de trítono de Mi\# a Si. Se considerarmos as quatro alturas iniciais - cujo movimento melódico evolui para a diagonalidade - está ausente deste movimento melódico estrutural somente o Si\#, para que fossem expostos os doze sons do total cromático. Esta exposição temática de Bartók exemplifica, modelarmente, a aplicação do 'princípio da complementaridade cromática' - a tendência à ocorrência dos doze sons do total cromático ou 'o livre e igual tratamento dos doze sons' - em vários níveis, da superfície da linha melódica à estrutura que suporta toda a textura

O Exemplo 5, também do Terceiro Quarteto, ilustra a aplicação do princípio da complementaridade cromática na elaboração de textura polifônica:

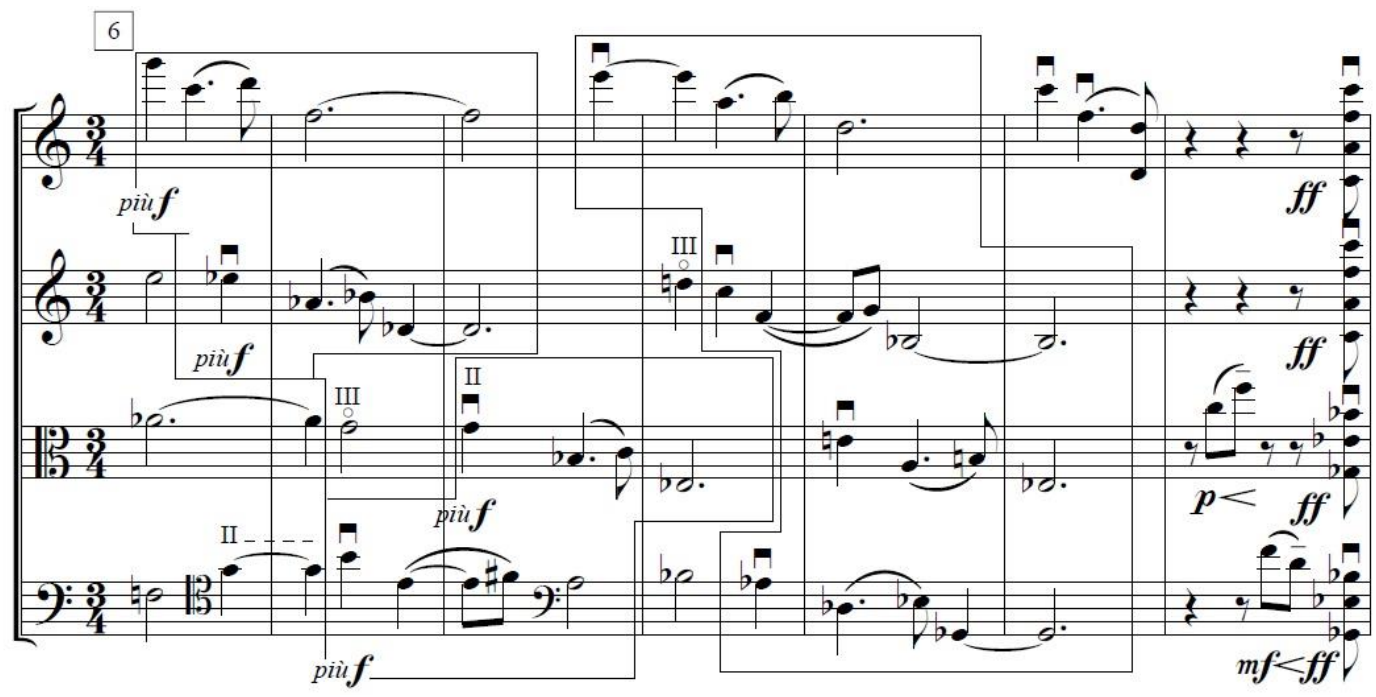




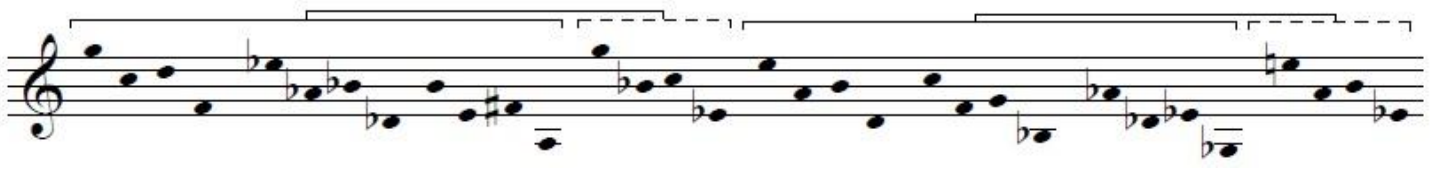

Exemplo 5: Emprego do modo dodecafônico, por Bartók, na composição de textura polifônica

Os três primeiros grupos de quatro notas formam o total cromático. $\mathrm{O}$ quarto grupo fixa a orientação de todo o trecho para o centro tonal Mib.

No Exemplo 6, extraído do Quarto Quarteto de Cordas, de 1928, compassos 4-9, o princípio da complementaridade cromática é aplicado na construção de textura que resulta na diagonalidade:
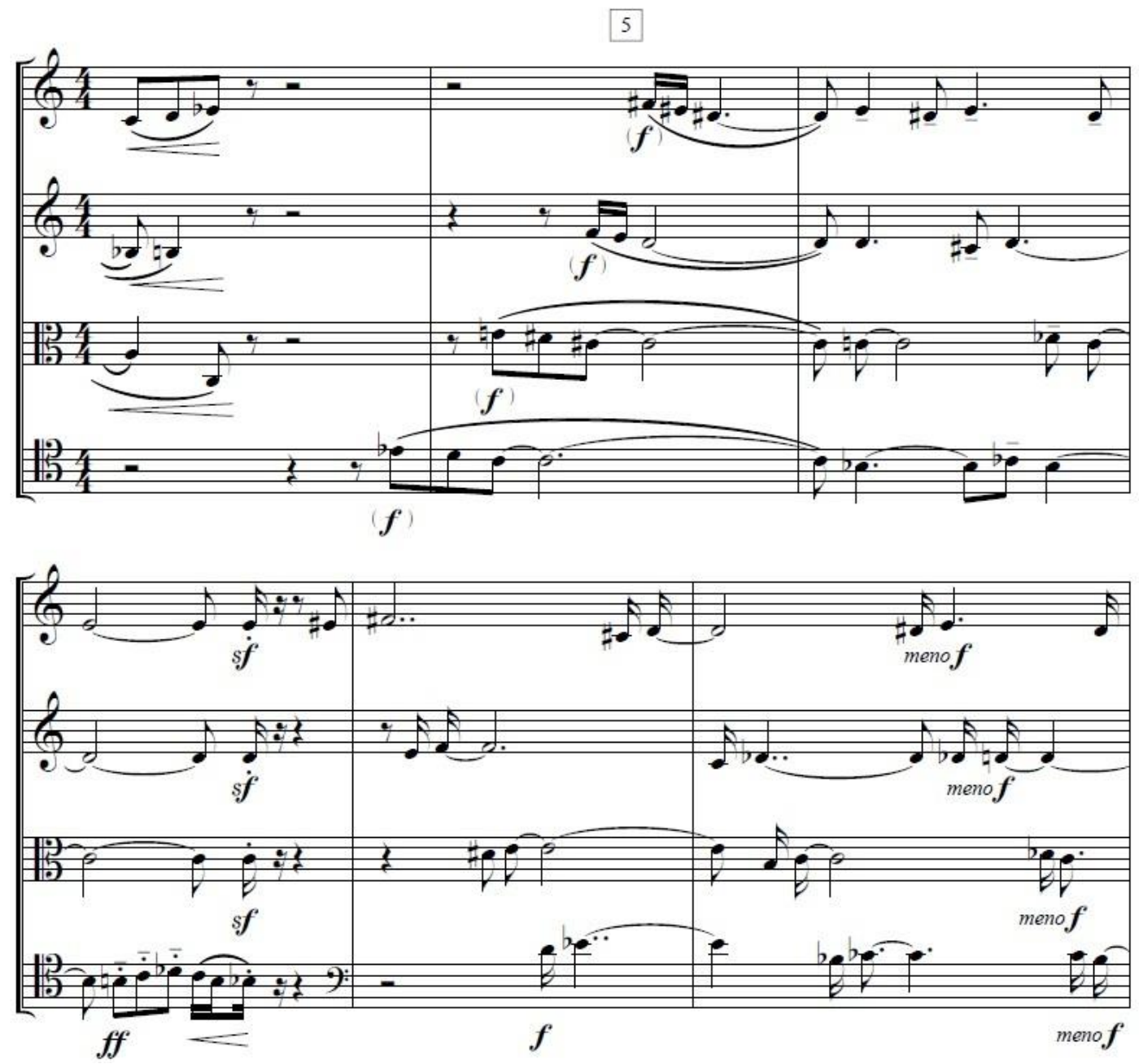

Exemplo 6: Aplicação do 'princípio da complementaridade cromática' na elaboração de texturas que resultam na diagonalidade

Bartók utiliza, neste extrato do Exemplo 6, todo o intervalo cromático da quinta aumentada de Sib a Fá\#. A textura evolui para o acorde de tons inteiros 
Sib-Dó-Ré-Mi, consolidada no compasso 10, para concluir, em sforzando fortissimo, no acorde que contém todas as alturas do intervalo cromático de Sib a Mi, no compasso 13.

O 'princípio da complementaridade cromática' assume muitas vezes na música de Bartók uma feição especial e única, definida por ele mesmo como polimodalismo cromático ${ }^{9}$, que expressa não somente o livre tratamento dos doze sons, mas, também, a instituição de hierarquias no interior do total cromático, que entendemos como combinações originadas de interações específicas, resistentes à generalização.

O 'princípio da complementaridade cromática', como o encontramos em Schoenberg, Bartók, Webern, Berg e outros, é exatamente o mesmo do qual nos apropriamos, mas ao qual damos uma aplicação particular e distinta. No nosso caso, o 'princípio da complementaridade cromática' atua na constituição mesma dos elementos motívico-temáticos, assim como na sua elaboração. É inerente ao processo de criação motívico-temático, orientando-o. Ao contrário de Schoenberg, que nas primeiras obras atonais decide por abandonar a elaboração motívico-temática, e por perseguir uma unidade na concepção que rege tanto a construção melódica quanto a harmônica, em que um mesmo princípio assume a regulação destas duas dimensões, no nosso caso o princípio da elaboração motívico-temática é o principal definidor da forma e coordenador das demais forças organizadoras, que se colam a uma estrutura determinada pela construção motívico-temática. Longe de assegurar a unidade de concepção melódica e harmônica, a complementaridade cromática, como a aplicamos, é um princípio comum às duas dimensões, mas não um princípio unificador. A simultaneidade ou dimensão harmônica implica numa abordagem específica, distinta das exigências impostas pelo desdobramento articulado da linha melódica. A complementaridade cromática ocorre, como o exemplificaremos, em três dimensões: horizontal ou melódica, vertical ou harmônica e na interação entre melodia e harmonia ou, assim denominamos esta interação, na diagonalidade. No Exemplo 7, analisamos a introdução da primeira das nossas Três Canções sobre Poemas de Fernando Pessoa, para identificar cada uma destas possibilidades:

\footnotetext{
${ }^{9}$ Em nosso cromatismo polimodal, entretanto, os sons abaixados [bemol] ou elevados [sustenido] não são absolutamente graus alterados; são componentes diatônicos de uma escala modal diatônica. [...] Em nossos trabalhos, tanto quanto em outros trabalhos contemporâneos, diversos métodos e princípios se entrecruzam. [...] Então, se dizemos que nossa arte musical é polimodal, isto apenas significa que a polimodalidade ou bimodalidade manifesta-se em seções maiores ou menores de nossa obra, algumas vezes apenas em um único compasso. [...] A salientar a diferença essencial entre atonalidade, politonalidade e polimodalidade, em uma palavra final sobre este assunto, podemos dizer que a música atonal não apresenta qualquer som fundamental, a politonalidade apresenta - ou supõe apresentar - vários deles, e a polimodalidade apresenta um único. (Bartók 1993, p. 367-370)
} 


\section{Dorme enquanto eu velo ...}
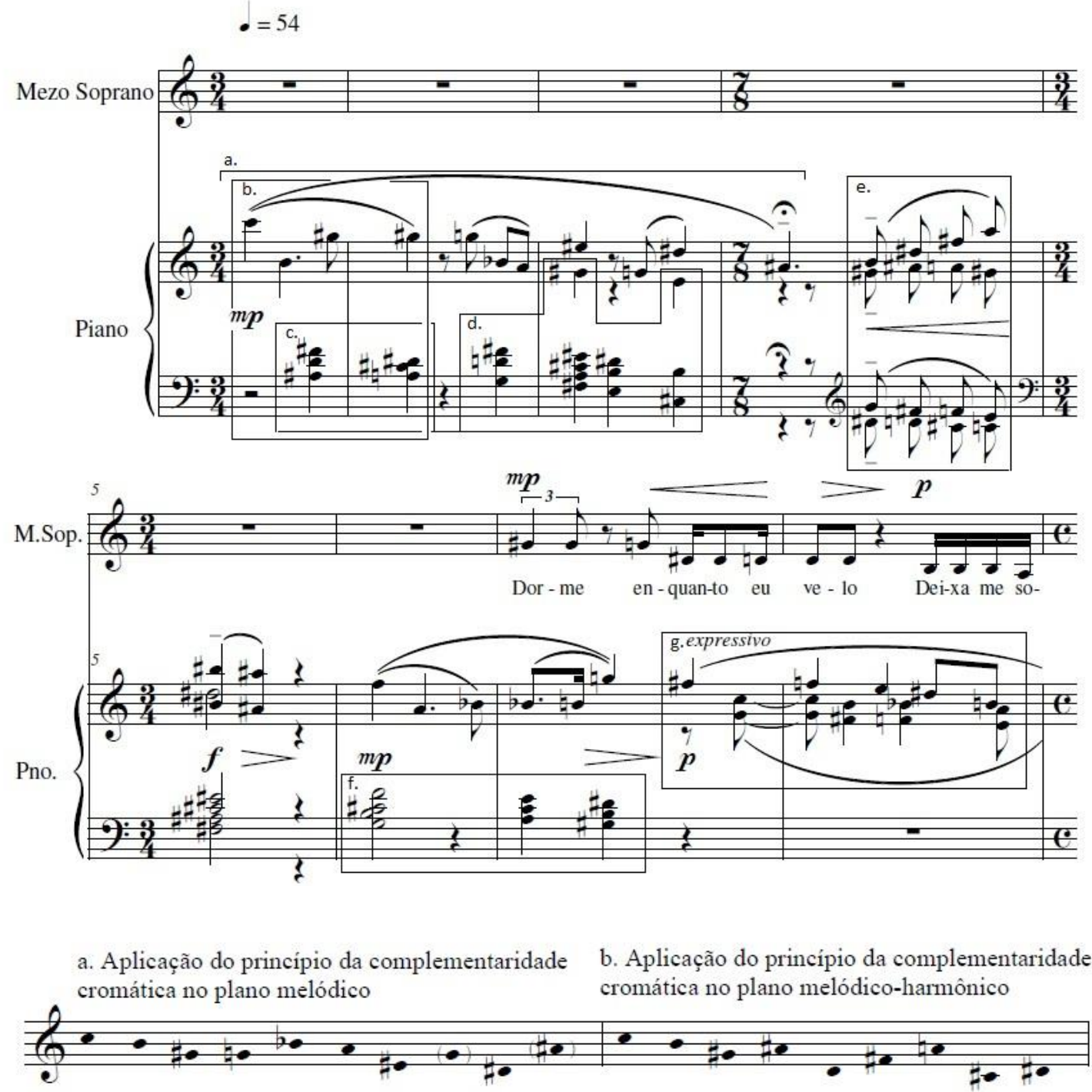

c.d. Aplicação do princípio da complementaridade cromática no plano harmônico

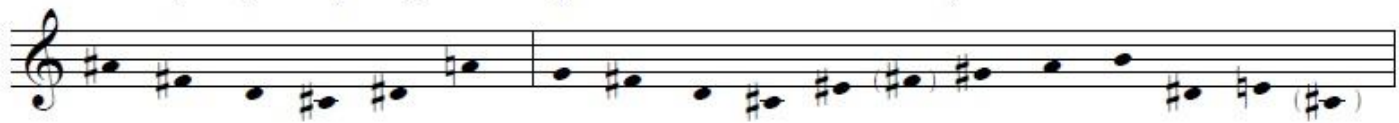

Exemplo 7: Aplicação do princípio da complementaridade cromática, ou seja, da tendência da ocorrência do total cromático nos planos melódico, harmônico e melódico-harmônico

Reconhece-se, no Exemplo 7, a tendência de se apresentar o total cromático, em consonância com o 'princípio da complementaridade cromática', mas a organização das alturas também se orienta pela predominância de determinadas relações intervalares, privilegiadas na própria constituição do 
tema, pela disposição estrutural das alturas em figuras simétricas, total ou parcialmente. Os acordes constituem-se com uma interválica própria, mas as relações de encadeamento são coordenadas pelo movimento melódico proeminente de semitom, como está explícito em e, f, g, do Exemplo 7. É evidente o caráter orientador e não-determinístico dos princípios que apoiam o processo criativo. Em todo e qualquer momento do processo composicional está salvaguardado o livre arbítrio do compositor. Cada passo da obra resulta de uma decisão de caráter empírico, que leva em conta as especificidades da história do processo criativo em decurso. Todas as decisões apoiam-se na exploração das potencialidades intrínsecas dos termos que organizam a textura musical.

O Exemplo 8 ilustra ainda outra vez, no primeiro tema do primeiro movimento de nosso Solo para Violoncelo, a aplicação do 'princípio da complementaridade cromática' na elaboração motívico-temática:
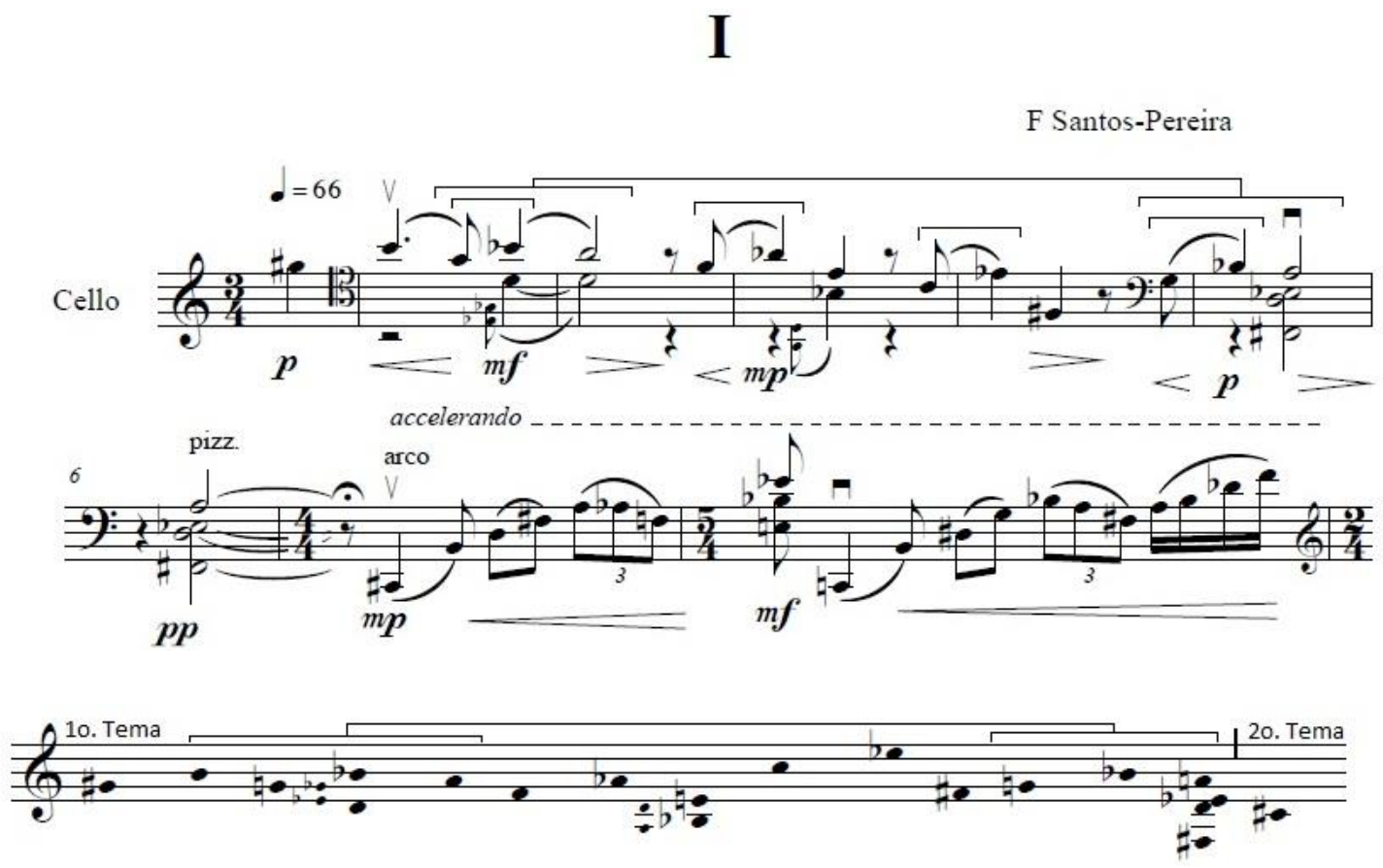

Exemplo 8: Primeiro tema, comp. 1 a 6, do primeiro movimento de Solo para Violoncelo. À tendência para a exposição do total cromático sobrepõe-se a ênfase no movimento melódico de terça menor. O motivo que inicia o tema é o mesmo que o conclui

Ao 'princípio da complementaridade cromática' une-se a predominância do intervalo de terça menor, presente em cada um dos motivos que compõe o primeiro tema. Impede a ocorrência do total cromático, no primeiro tema, a ausência do Dó\#, assim posto em 'relevo negativo'. É o Dó\#, agora em 'relevo positivo' potencializado pela ausência no primeiro tema, que inicia, no compasso 7, o segundo tema. Ao momento da ocorrência do total cromático, ao invés da 
ideia de completude, é associada uma articulação formal, contrastante e tensionadora, que resulta em uma articulação do discurso musical.

A tendência ao total cromático tem por função provocar o movimento, atua como agente da instabilidade. A ocorrência efetiva do total cromático guarda a potencialidade da atuação como termo conclusivo, em figura cadencial, com a função de restabelecer a estabilidade ou repouso, que empreguei de forma sistemática nas Peças Breves para Piano, de 2011, (vide Exemplo 9), onde o conceito de complementaridade cromática já é utilizado associado a qualquer intervalo musical, não exclusivamente ao intervalo de oitava. A figura cadencial que conclui a primeira peça demonstra com clareza as características conclusivas assumidas pela efetiva ocorrência do total cromático, neste caso o total cromático do intervalo musical esquemático de sexta menor, de Fá a Réb.

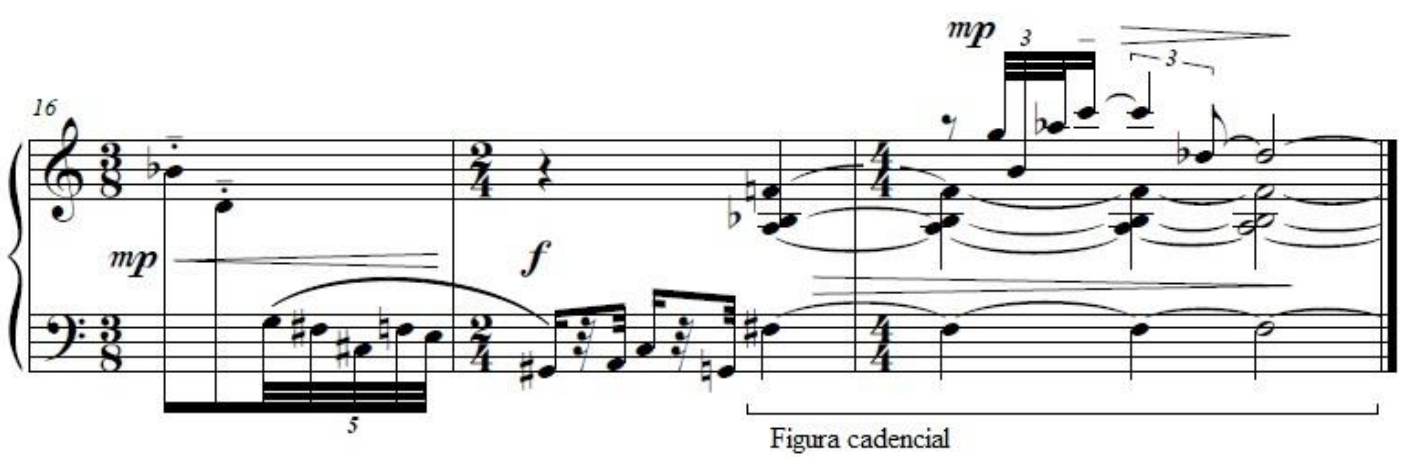

Exemplo 9: Figura cadencial que conclui a primeira das Peças Breves para Piano. Ilustra a função conclusiva assumida pela efetiva ocorrência do total cromático do intervalo esquemático de sexta menor, de Fá a Réb

No Exemplo 10, tomado da segunda das minhas Peças Breves para Piano, a figura cadencial que conclui a primeira seção, compasso 6, extrai a sua função formal do total cromático do intervalo esquemático de Mib a Sol\#. O motivo subsequente, episódico, restaura o movimento antes contido pela figura cadencial. A sua função formal, de provocar a instabilidade e o movimento, resulta da tendência ao total cromático do intervalo esquemático de Lá a Mib, que não se efetiva pela omissão do Réb. A aparição subsequente do Réb já se associa a um novo material temático, que não admite a vinculação resolutiva ao motivo precedente. 


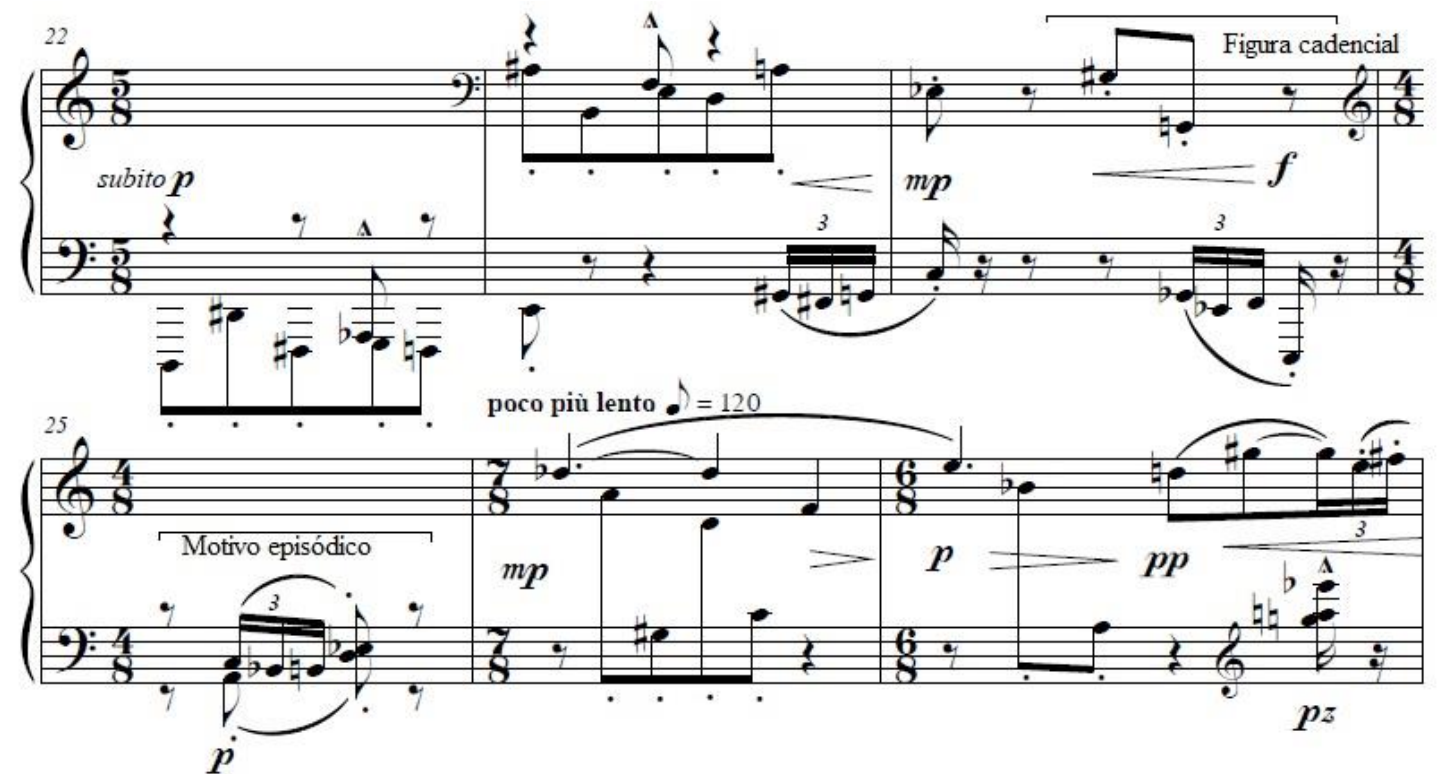

Exemplo 10: Figura cadencial que conclui a primeira seção da segunda das minhas Peças Breves para Piano. A função conclusiva está associada à ocorrência do total cromático do intervalo musical esquemático de Mib a Sol\#. O motivo episódico subsequente reinstaura o movimento contido pela figura cadencial. A função de provocar o movimento está associada à tendência ao total cromático do intervalo esquemático de Lá a Mi bemol, total cromático que não se realiza pela ausência do Dó\#

\section{2 - O eixo cromático}

A expressão 'eixo cromático' é empregada para designar uma progressão melódica estrutural, em movimentos descendentes ou ascendentes de semitom. A ocorrência de eixos cromáticos é detectável desde a adoção do temperamento. Encontramo-los, p. ex., em Bach, Partita 5, compassos 37 a 41 (vide Exemplo 11).

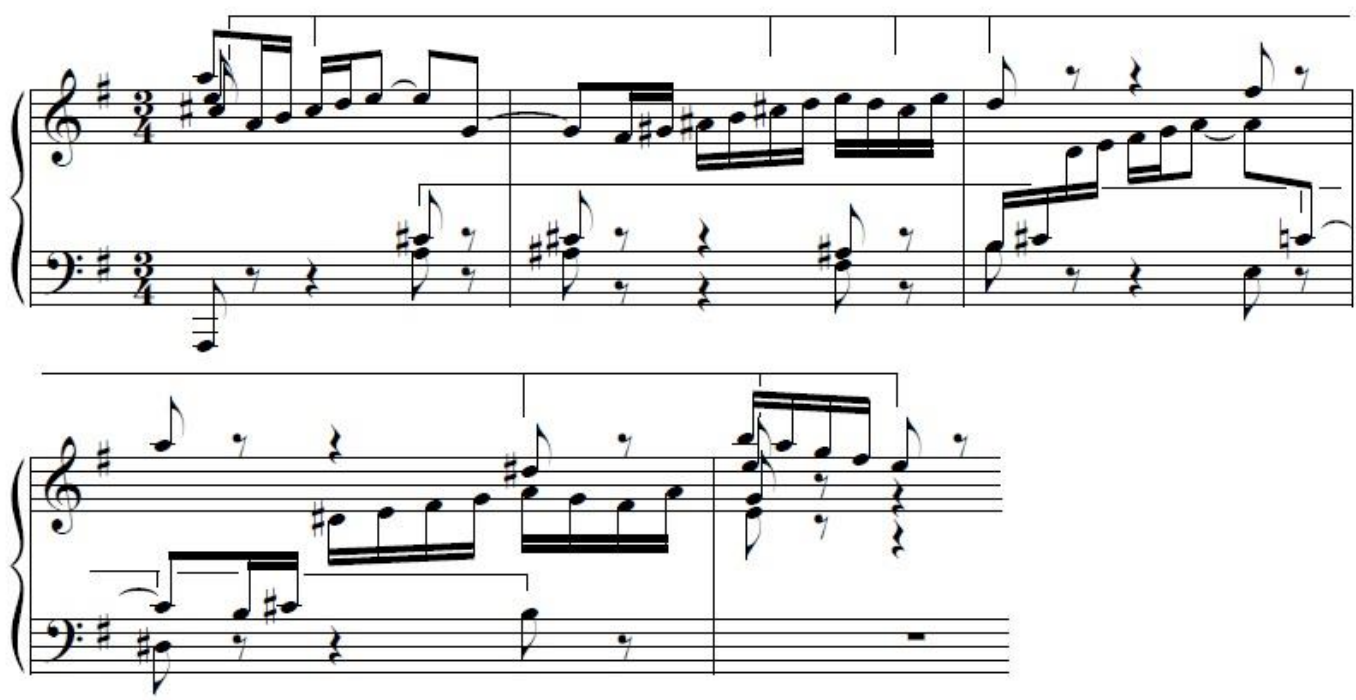

Exemplo 11: Exemplo de 'eixos cromáticos' em Bach. O 'eixo cromático' superior ascende de Dó\#4 a Mi4 e o inferior descende de Dó\#3 a Si2 
Encontramo-los, os 'eixos cromáticos', no primeiro movimento da Sonata para Violino e Piano no 11 de Mozart, KV 379, compassos 15 a 17 (Exemplo 12).

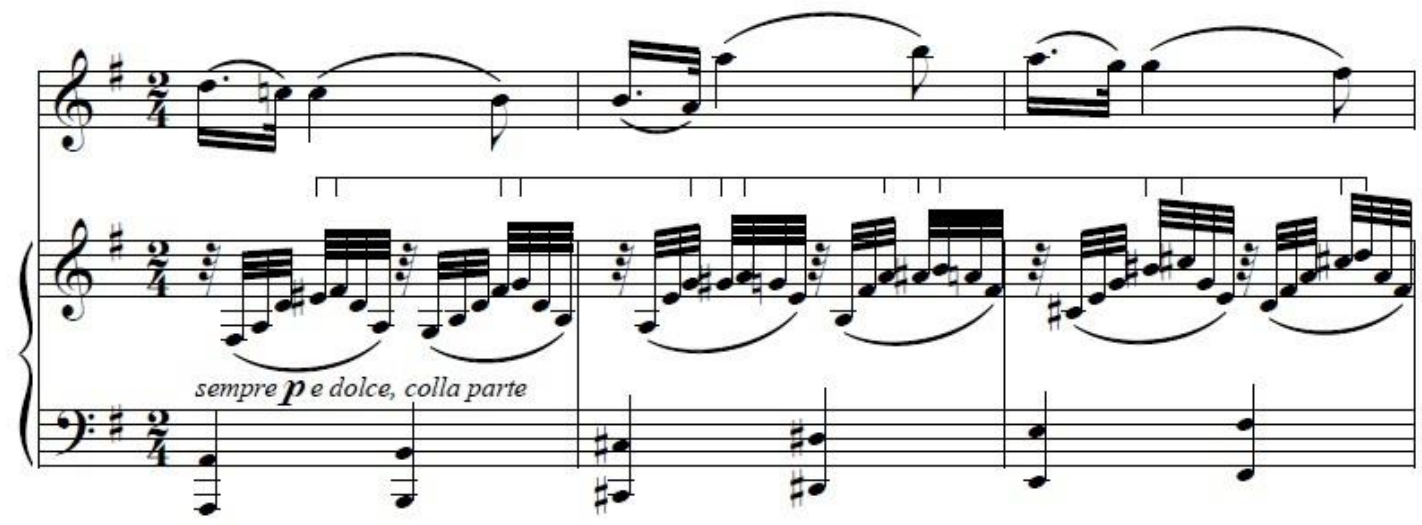

Exemplo 12: Exemplo de 'eixo cromático' em Mozart. O ‘eixo cromático' ascende de Mi\#3 a Ré4

Na música tonal, o 'eixo cromático' é um fenômeno secundário que, entretanto, deixa manifesta a potencialidade cromática do sistema. A sua ocorrência, constatamos, associa-se muito mais à natureza da progressão harmônica - geralmente em encadeamentos de dominantes ou movimentos cadenciais - do que à elaboração temática ou melódica.

Contentemo-nos com estes exemplos tonais e efetuemos um salto para reencontrar os 'eixos cromáticos' na música de Alban Berg. Identifiquemos os eixos cromáticos na primeira frase de Sahst du nach dem Gewitterregen op. 4, no 2 (vide Exemplo 13).

Apesar da densidade cromática da música de Berg, e da mesma forma com a de Schoenberg, não são tão recorrentes, quanto se poderia esperar, a presença de 'eixos cromáticos', que, assinalemos, não se confundem com o movimento melódico cromático. Os 'eixos cromáticos' raramente se fazem perceptíveis, atuando num nível estrutural, enquanto o cromatismo melódico situa-se, claramente perceptível, na superfície da textura musical. 

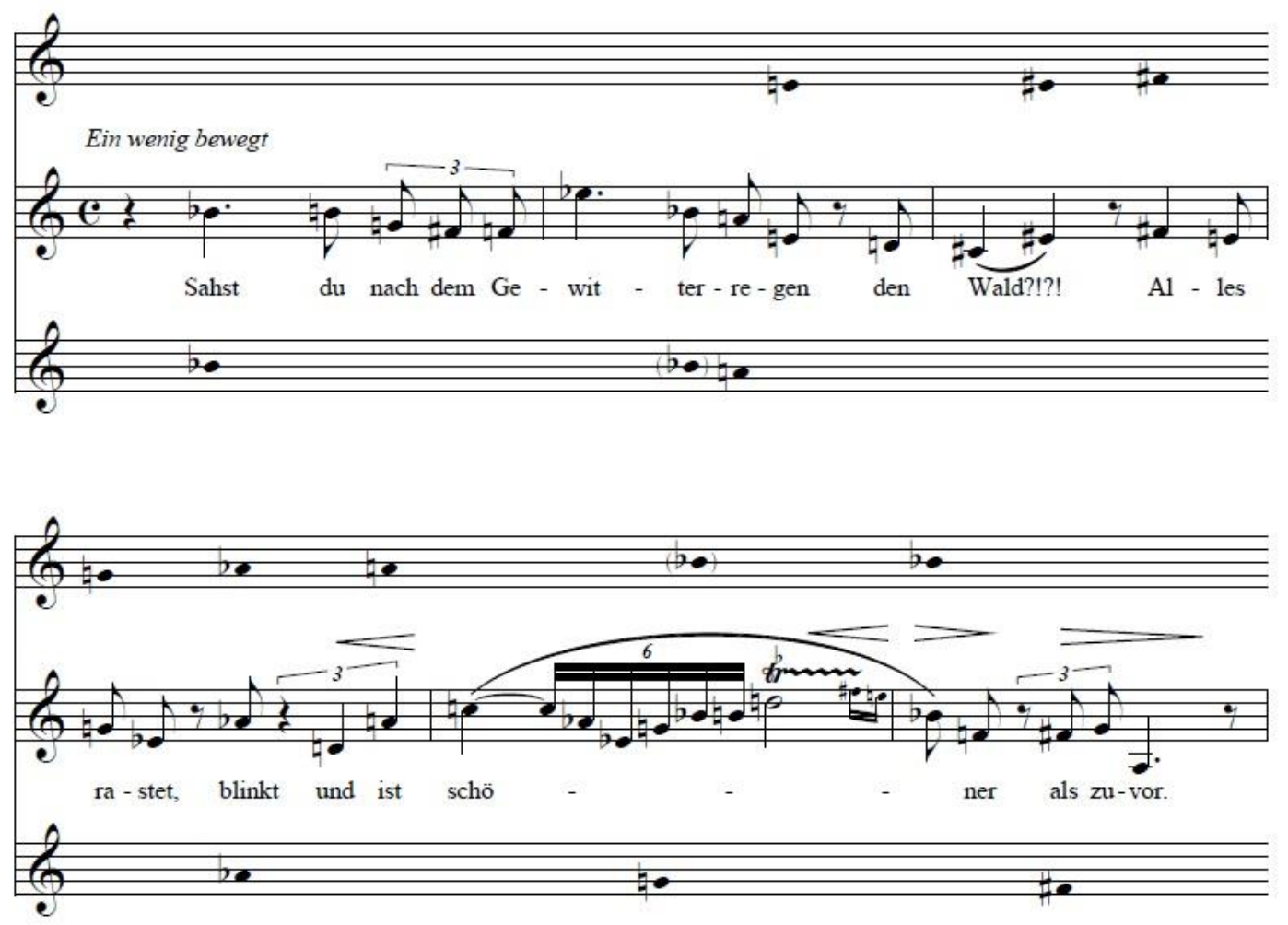

Exemplo 13: Identificação de 'eixos cromático na primeira frase de Sahst du nach dem Gewitterregen op. 4, no 2, de Alban Berg

Os 'eixos cromáticos' são decorrência natural da aplicação da técnica do agrandissement asymétrique, idealizada por Messiaen. São inúmeros os exemplos encontrados na sua obra. Destacamos, especialmente, a sua ocorrência em Vingt Regards sur l'Enfant-Jésus, para piano solo. No caso específico da maneira como Messiaen aplica o agrandissement asymétrique, o 'eixo cromático' quase sempre perfaz o total cromático, como o ilustra III - L'échange.

Para caracterizarmos a quase onipresença de eixos cromáticos - embora como fenômeno secundário, o que não nos permite afirmar que foram postos a atuar na organização da textura musical -, analisamos no Exemplo 14 a ocorrência, rara e, arriscamo-nos a dizer, possivelmente acidental, em Lemma Icon - Epigram, de Ferneyhough (1982). 


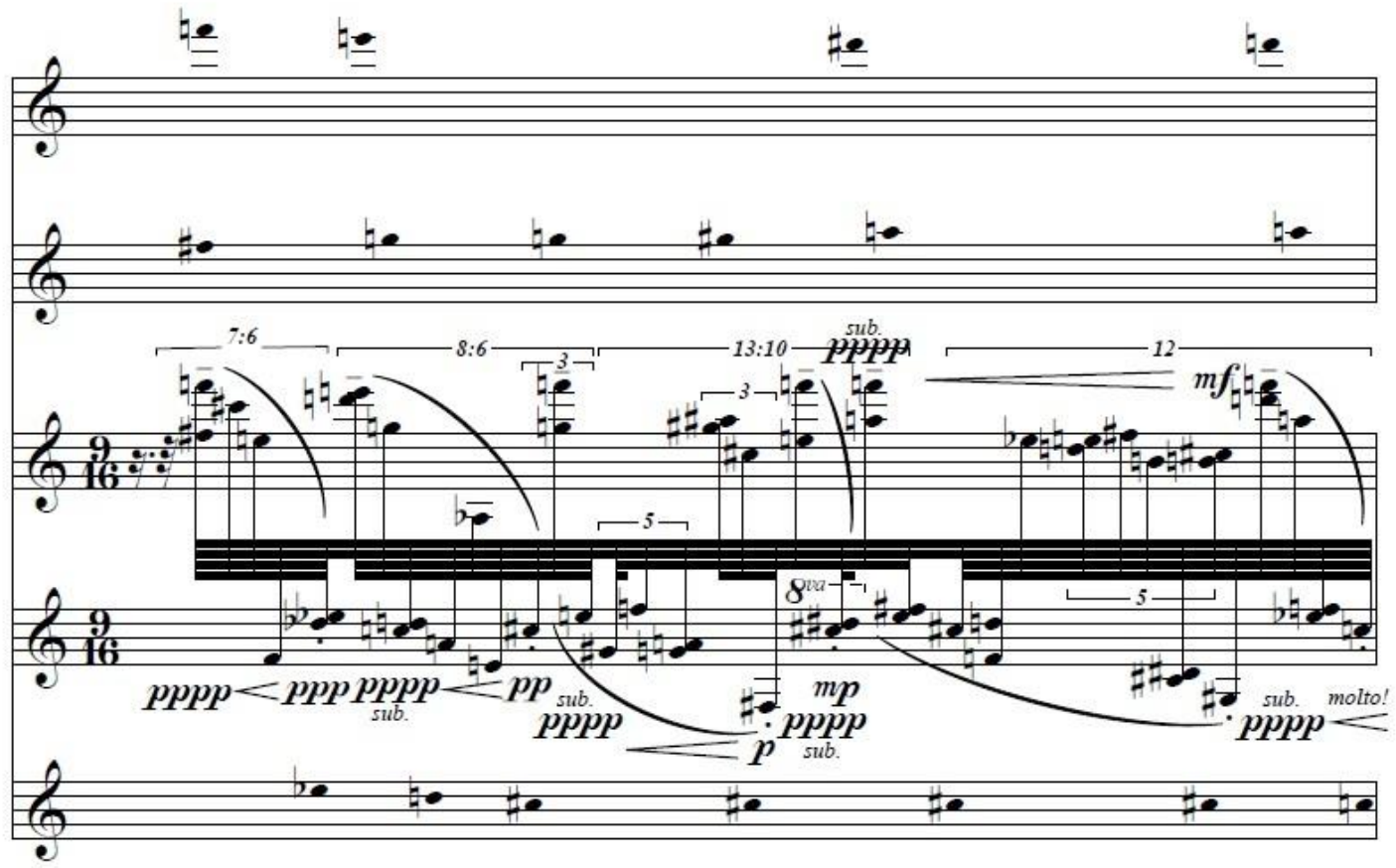

Exemplo 14: Identificação de eixos cromáticos em Lemma - Icon - Epigram, comp. 34, de Ferneyhough (1982)

Chamamos a atenção para o pedal em Fá, em tenuto na região aguda, sem dúvida posto deliberadamente a determinar a composição melódica, ao contrário dos 'eixos cromáticos' - fenômeno secundário e acidental na música de Ferneyhough, em razão, sobretudo, da raridade e do emprego não sistemático dotados de uma atuação localizada, não intencional.

De modo geral, identificável e recorrente desde a adoção do temperamento, percebemos na ocorrência, mesmo não intencional, dos 'eixos cromáticos' a emergência da função direcional. Encontramo-los, no conjunto dos exemplos citados, sempre somados a diversas outras forças organizadoras dotadas, nestes contextos, de muito maior poder organizador - como, por exemplo, o encadeamento tonal, as técnicas de elaboração a partir de motivos próprias das primeiras obras atonais, a sistematização de fundo modal ou serial das alturas -, mas, ainda assim, distinguível o aporte significativo à função direcional.

Apropriamo-nos do que designamos por 'eixo cromático' para fazer do seu emprego metódico o principal meio de imprimir direcionalidade no interior dos movimentos melódicos e harmônicos. Como os empregamos, os 'eixos cromáticos' não são predeterminados. Definem-se no mesmo momento em que são construídas a linha melódica e as progressões harmônicas, a orienta-las. A linha melódica, assinalemos, jamais se reduz a uma ornamentação ou elaboração em torno de um 'eixo cromático'. Do mesmo modo, este não interfere na 
hierarquia do movimento melódico, não transfere para o plano melódico o valor e a posição estrutural privilegiada que têm as alturas que compõem o 'eixo cromático'. São termos paralelos e sobrepostos, mas com funções estruturantes distintas. O 'eixo cromático' incute direcionalidade, enquanto a elaboração motívico-temática - materializada na linha melódica - organiza a inteligibilidade das relações pontuais assim como a forma musical.

No exemplo seguinte, expomos os 'eixos cromáticos' que, junto com o 'princípio da complementaridade cromática', orientam a composição melódica e harmônica da primeira seção do segundo movimento de minha peça Solo para Violoncelo (vide Exemplo 15).
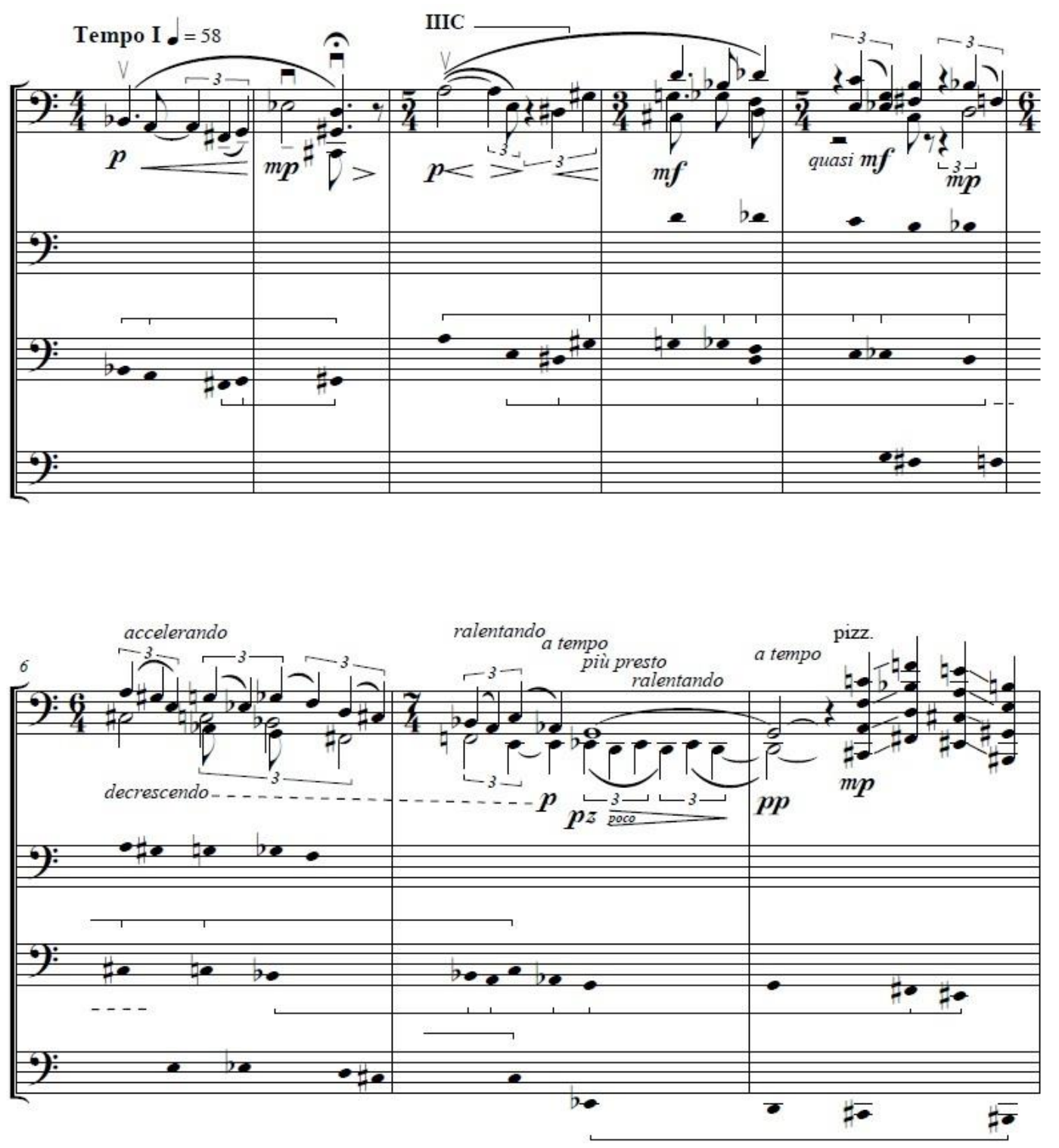

Exemplo 15: Exposição dos 'eixos cromáticos' que orientam a composição da primeira seção do segundo movimento de Solo para Violoncelo. 
Os 'eixos cromáticos' se dispõem em camadas, imbricam-se, fundem-se, multiplicam-se numa interação complexa cuja finalidade é a de imprimir direcionalidade à textura musical.

\section{3 - A elaboração motívico-temática}

O conceito da elaboração motívico-temática, em nossa prática composicional, é fundamental na materialização da concepção formal. Na sua aplicação agem, concomitantemente, todas as forças organizadoras que definem, potencializam e desenvolvem as relações locais, a sua constituição em seções até a configuração da forma como um todo. A elaboração motívico-temática aproxima-se da técnica de variação em muitos aspectos, especialmente com relação às técnicas de transfiguração do motivo. Cada um dos termos que compõe e caracteriza o motivo ou tema é maleável, suficientemente neutralizado, e tratado com a flexibilidade que exige o exercício das funções formais que são postos a desempenhar. Os termos que suportam e criam os vínculos no processo da elaboração motívico-temática são, principalmente, o ritmo e o timbre. Especialmente, o ritmo - a preservar substancialmente o gesto - é o termo mais efetivo na conservação dos laços entre os diversos elementos derivados, mesmo sob a ação das mais poderosas forças transformadoras, a assegurar, perceptivelmente, ao nível da superfície da música, a apreensão tanto da variação propriamente dita, quanto da natureza dos vínculos que sustentam o próprio processo de variação. A análise de alguns exemplos ilustrará o processo. Tomemos o exemplo da elaboração motívico-temática desenvolvida a partir do motivo inicial do primeiro movimento de Solo para Violoncelo (Exemplo 16).

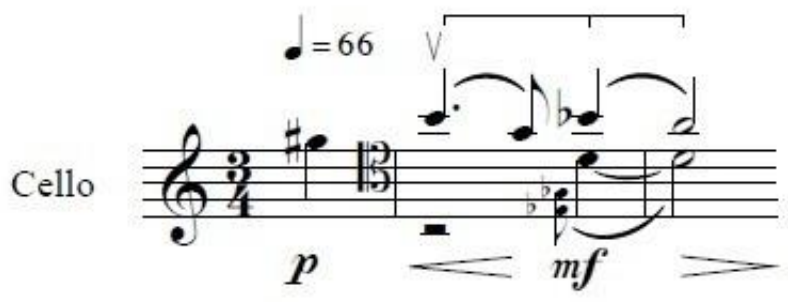

Exemplo 16: Motivo inicial do primeiro movimento de Solo para Violoncelo. O movimento cromático indicado é tomado como termo de referência nas transformações aplicadas.

No Exemplo 17 acrescenta-se um prefixo, também de valor motívico, ao tema inicial, reduzido este ao seu movimento cromático essencial, com variação no registro a transformar o intervalo de semitom no seu inverso, a sétima maior. No compasso 27, o motivo inicial, apesar de quase totalmente transfigurado, ainda retém suas características estruturais: o movimento cromático; o movimento melódico primeiro de sexta maior invertido em terça menor; a 
articulação do movimento cromático, mas agora pela célula melódica Fá 4 - Mi 4 em colcheias, cuja articulação é característica desta variação. Nos compassos 29 e 30 incorpora-se à elaboração sobre o motivo inicial, a articula-lo, novo motivo a partir do qual se construirá a seção subsequente, do compasso 32 ao 43. A incorporação de um motivo à elaboração de um outro, a intercambiar características, integrando-os em um mesmo movimento, é recurso recorrente.

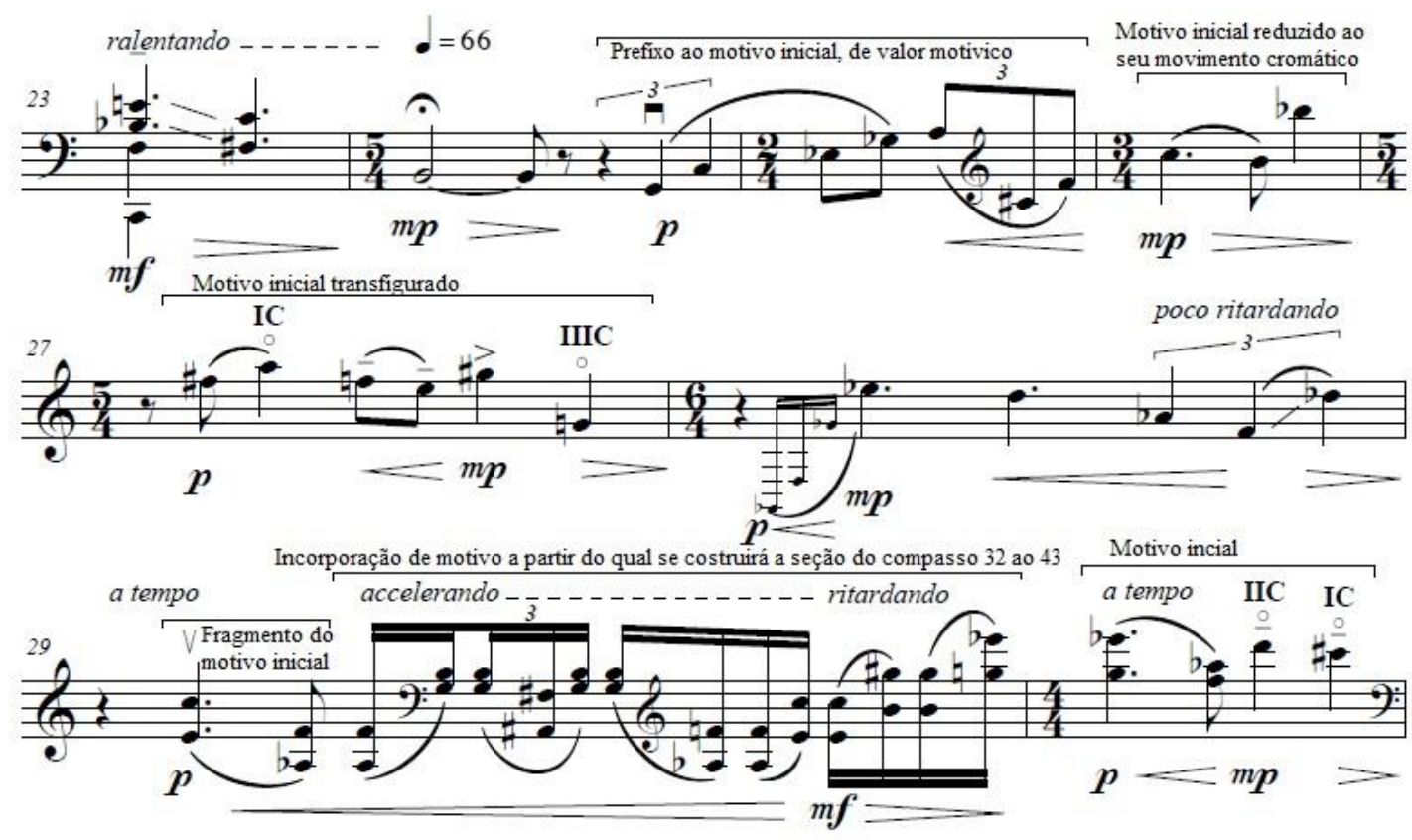

Exemplo 17: Elaboração motívico-temática a partir do motivo inicial do primeiro movimento de Solo para Violoncelo

A elaboração analisada no Exemplo 17 fornecerá os elementos para a seção, compassos 44 a 56, que concluirá a primeira parte, compassos 1 a 56, deste primeiro movimento de Solo para Violoncelo. A elaboração toma como referência, igualmente, tanto o motivo inicial (A) como a sua versão transfigurada (At). Também o prefixo ao motivo inicial (P) é abraçado pelo processo de elaboração motívico-temática. 

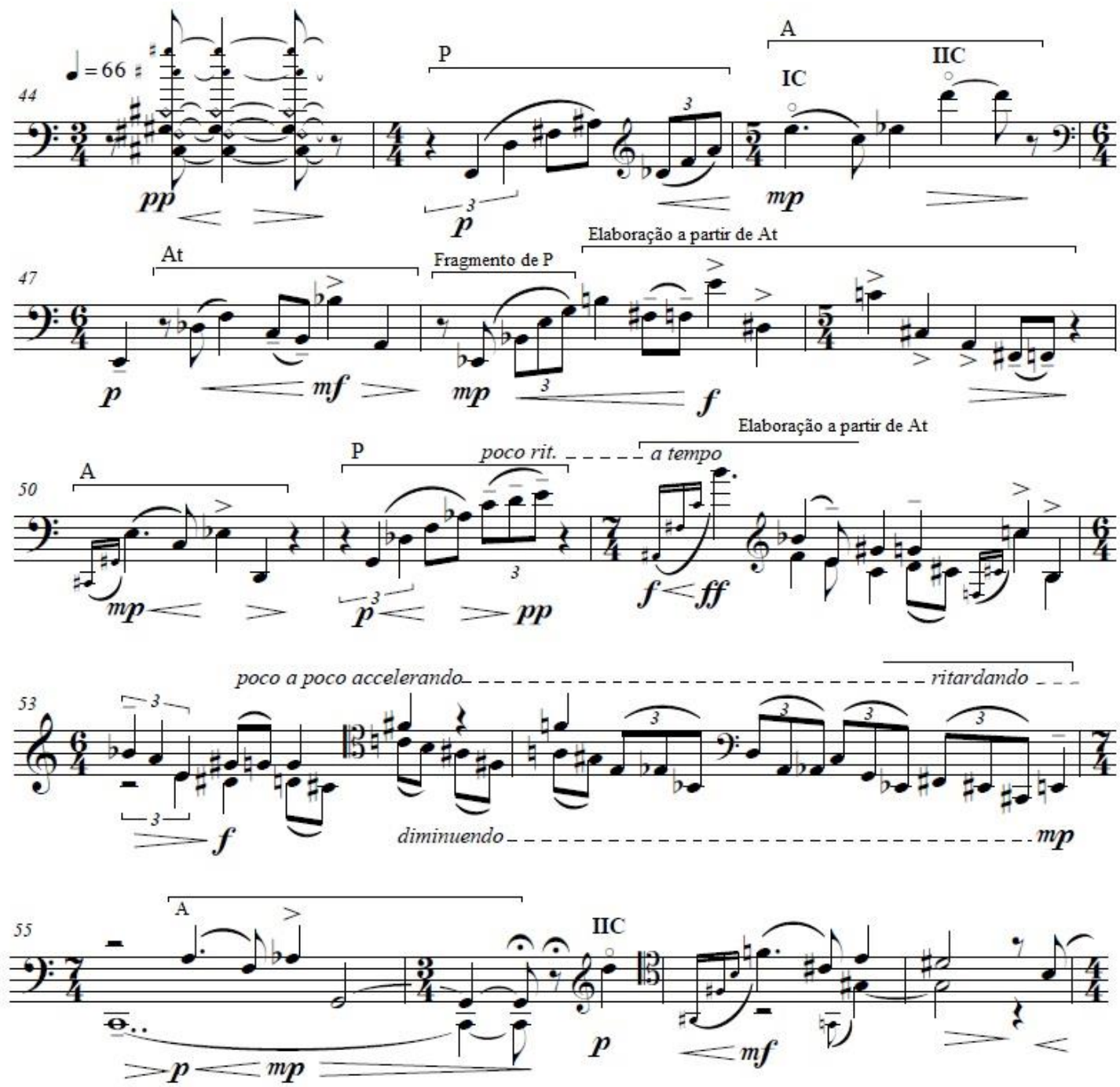

Exemplo 18: Seção que conclui a primeira parte do primeiro movimento de Solo para Violoncelo, composta a partir da elaboração motívico-temática do motivo inicial (A), sua transfiguração (At) e da figura que lhe serve de prefixo $(\mathrm{P})$

Os Exemplos 19 e 20 ilustram a aplicação da elaboração motívico-temática posta a operar de um modo muito próximo à prática da variação. A segunda peça das Peças Breves para Piano tem a forma $\mathrm{A}^{1}-\mathrm{B}-\mathrm{A}^{2}$, onde $\mathrm{A}^{2}$ é a elaboração - poderse-ia dizer a variação - de $\mathrm{A}^{1}$. 


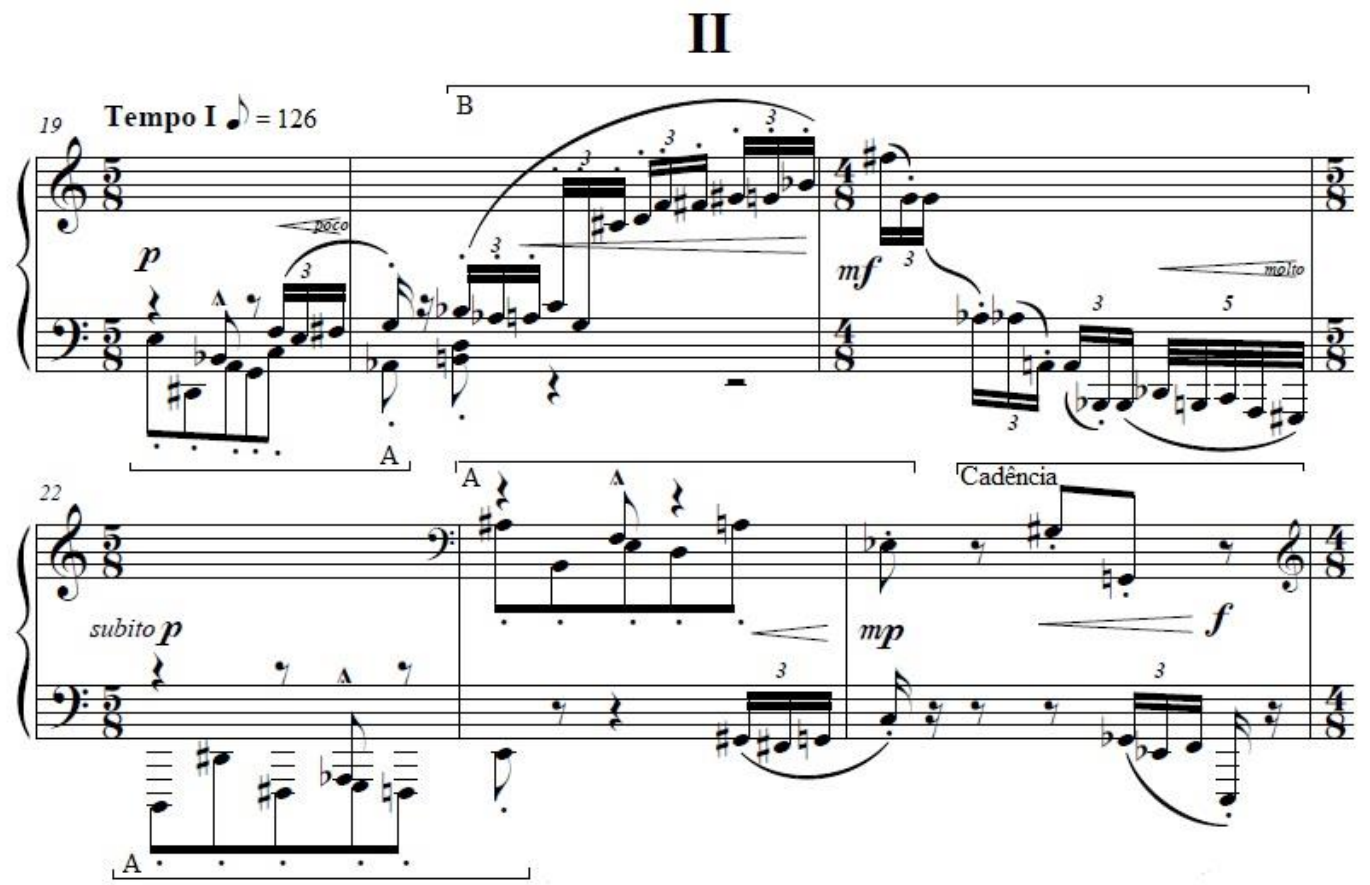

Exemplo 19: Seção $\mathrm{A}^{1}$ da segunda das Peças Breves para Piano



Exemplo 20: Seção $\mathrm{A}^{2}$ da segunda das Peças Breves para Piano, consequência da elaboração motívico-temática ou variação, num sentido amplo, da seção $\mathrm{A}^{1}$, evidenciada a elaboração pelo paralelismo formal 
A dissecação da elaboração motívico-temática faz supor um planejamento meticuloso. Em verdade, o que se faz é explorar com a maior atenção as potencialidades das relações instauradas no interior do motivo ou tema, de acordo com um projeto formal suscetível de modificação pelas próprias possibilidades engendradas.

A elaboração motívico-temática permite um enfrentamento sistemático da problemática da repetição e do retorno dos elementos motívicos, temáticos e seções formais. O conceito de elaboração motívico-temática já traz em si a ideia de retorno. Mas traz também em si a ideia de variação, que faz de cada retorno uma experiência renovada. Cada motivo incorpora nas suas reapresentações a materialidade do próprio processo da elaboração, que atravessa o movimento ou a obra por inteiro. Neste processo, jamais um motivo ou tema será reapresentado literalmente. É posta em jogo uma conjunção de forças que ao mesmo tempo conserva os elementos identificadores essenciais, mas renova termos estruturantes que colocam estes mesmos elementos identificadores sob uma nova perspectiva. Dentre estes termos estruturantes, as alturas são os termos que mais sofrem a ação das forças desencadeadores dos mecanismos de variação, não restando, muitas vezes, mais do que o perfil original, este mesmo transformado pela expansão ou retração das células motívicas. O processo de elaboração se dá na própria superfície da música, e não nos seus subterrâneos, oculto da percepção musical. É um processo empírico, que alcança todas as camadas do processo de elaboração, mantendo-os, por todo o tempo, na superfície do fenômeno musical, diretamente acessível ao escrutínio dos movimentos perceptivos. Por ser a música uma arte do tempo, a memória - a capacidade de destacar um fato musical na linha do tempo e associá-lo a fatos anteriores e posteriores - é o instrumento por meio do qual se reconhece e reconstitui o processo de elaboração. É, também, pela ação da memória que se constitui e consolida a hierarquização entre os diversos termos, estabelecida no próprio processo de elaboração pelo papel estrutural assignado a cada motivo e tema.

\section{0 - Conclusão}

À guisa de conclusão destas ponderações acerca da técnica musical, acrescentamos que no aspecto rítmico tem-se levado em conta as críticas de Grisey (1987), defensor da fenomelogia da percepção, que expõe a fragilidade das noções de liso e estriado, retrogradável e não-retrogradável, simetria e assimetria, categorias comumente dualísticas e arbitrárias. Grisey propõe "uma escala de complexidade - sem dúvida igualmente arbitrária - mas que tem a vantagem de retornar ao fenômeno dos tempos musicais como são percebidos e permitir uma continuidade apreensível" (Grisey 1987, p. 244). Aderimos à diretiva de Murail 
(2005, p. 153) quanto à "recusa da complexidade originada da superposição de nquiálteras ou compassos irracionais, tão inúteis quanto arbitrários". Diretiva esta em sintonia com um dos preceitos essenciais para se encontrar um lugar no universo espectral: "manter em mente a relação entre conceito e percepção" (Murail 2005, p. 152). Na elaboração motívico-temática, é o ritmo, voltamos a dizê-lo, que se põe a exercer o papel de principal elo entre as várias elaborações. Do movimento melódico preserva-se, sobretudo, o perfil, a submeter as relações intervalares a permanentes forças reestruturadoras. Das relações rítmicas, muito mais estáveis, guardam-se as características fundamentais e estruturantes que dão coerência e explicitam o processo de elaboração.

Tem-se plena consciência da imprecisão das indicações da dinâmica. Mesmo assim, optamos por uma escrita detalhada, mas possível, que não despreza a fenomenologia da percepção, consistente com a instrumentação, preocupada não com a exatidão, mas com a relatividade, a ser construída na execução, entre as diversas indicações. Com a dinâmica conduzimos a evolução da ênfase no discurso musical, o que, num nível macroscópico, é um dos fundamentos na definição da forma.

A escolha da tessitura tem influência decisiva no caráter das entidades harmônicas e dos motivos. Os acordes complexos, por exemplo, especialmente aqueles com mais do que seis alturas distintas, dependem ainda mais de uma empírica, porém cuidadosa, escolha da tessitura para ajustar-se, a cada momento, às intenções expressivas. Estas têm que ser deliberadas, afastadas da gratuidade seja da agressividade, seja da ironia, seja da ausência de intenção expressiva. ${ }^{10}$

O timbre atua, proeminentemente, junto à rítmica, na formação dos elos no processo da elaboração motívico-temática. Mas, também, na articulação formal, onde a caracterização timbrística desempenha um papel fundamental. É assim tanto nas Canções para Orquestra sobre textos de Alexei Bueno, para voz feminina e orquestra, quanto na obra Solo para Violoncelo.

\footnotetext{
${ }^{10}$ A este respeito, a fazer a crítica (autocrítica?) ao serialismo integral, escreve Boulez (1972, p. 23): “[...] a obra não chega a se organizar segundo uma coerência probatória, ela soa mal; sua agressividade não é sempre deliberada." (negrito nosso)
} 


\section{Referências}

1. Bartók, Béla. 1993. Essays (Selected and edited by Benjamin Suchoff). Lincoln: University of Nebraska Press.

2. 1945. The Strings Quartets. New York: Boosey \& Hawkes.

3. Berg, Alban. 1953. Fünf Orchesterlieder. Wien: Universal.

4. Boulez, Pierre. 1972. A música hoje. São Paulo: Perspectiva.

5. Bueno, Alexei. 1998. Poemas Reunidos. Rio de Janeiro: Nova Fronteira.

6. Debussy, Claude. 1989. Monsieur Croche e outros ensaios sobre música. Trad. Raquel Ramalhete. Rio de Janeiro: Nova Fronteira.

7. Ferneyhough, Brian. 1982. Lemma-Icon-Epigram. London: Peters.

8. Grisey, Gérard. 1987. Tempus ex Machina: A composer's reflections on musical time. Contemporary Music Review, v.2, p.239-275.

9. Hindemith, Paul. 1945. The Craft of Musical Composition, Book I Theoretical Part. English Translation by Arthur Mendel. London: Schott.

10. Koblyakov, Lev. 1990. Pierre Boulez: a world of harmony. Chur: Harwood.

11. Lendvai, Erno. 1983. The workshop of Bartók and Kodály. Budapest: Ed. Musica.

12. Lévi-Strauss, Claude. 2004. O cru e o cozido. Trad. de Beatriz Perrone-Moisés. São Paulo: Cosac \& Naify.

13. . 1997. Olhar Escutar Ler. Trad. de Beatriz PerroneMoisés. São Paulo: Companhia das Letras.

14. Menezes, Flo. 1996. Um Olhar Retrospectivo sobre a História da Música Eletroacústica. In: Menezes, Flo (org.). Música Eletroacústica História e Estéticas, p. 17-48. São Paulo: EDUSP.

15. Messiaen, Olivier. 1994. Vingt Regards sur l'Enfant-Jésus. Paris : Durand.

16. Morin, Edgar. 2007. Introdução ao Pensamento Complexo. Trad. de Eliane Lisboa. 3a ed. Porto Alegre: Sulina.

17. Murail, Tristan. 2005 (April/June). Target Practice. Translated by Joshua Cody. Contemporary Music Review v. 24, n. 2/3, p. 149-171.

18. Nattiez, Jean-Jacques. 2005. O combate entre Cronos e Orfeu. Ensaios de semiologia musical aplicada. Tradução de Luiz Paulo Sampaio. São Paulo: Via Lettera.

19. Pousset, Damien. 2000. The Works of Kaija Saariaho, Philippe Hurel and Marc-André Dalbavie - Stile Concertato, Stile Concitato, Stile Rappresentativo. 
Translated by Joshua Fineberg and Ronan Hyacinthe. Contemporary Music Review, v. 19, part 3, p. 67-110.

20. Rameau, Jean-Philippe. 1971. Treatise on Harmony. Translated by Philip Gossett. New York: Dover.

21. Rose, François. 1996. Introduction to the Pitch Organization of French Spectral Music. Perspectives of New Music, v. 34, no. 2, Summer, p. 6-39.

22. Schaeffer, Pierre. 1952. A la Recherche d'une musique concrète. Paris : Éditions du Seuil.

23. Schoenberg, Arnold. 1913. Sechs Kleine Klavierstücke. Wien: Universal.

24. 1979. Armonia. Traduccíon de Ramon Barce. Madrid:

Real Musical.

25. . 1984. Style and Idea. Edited by Leonard Stein. Translations by Leo Black. Berkeley: University of California Press.

26. Stravinsky, Igor. 1977. Poética Musical. Versión castellana de Eduardo Grau. Madrid: Taurus.

27. Stravinsky, Igor; Craft, Robert. 1984. Conversas com Igor Stravinsky. Tradução de Stella Rodrigo Octavio Coutinho. São Paulo: Perspectiva.

28. Thurlow, Jeremy. 2010. Metaboles as a Fork in the Road: Twin Paths in Dutilleux's Later Music. Contemporary Music Review, v. 29 Issue 5, p. 485-496. 